\title{
Re-emergence of Paper Marriage discourse as Immigration Fraud
}

by:

Sugandha Chatterjee, MBA, Ryerson University, 2017.

B.E. - Computer Science and Engineering, Chhattisgarh Swami Vivekananda Technical University, India, 2010.

\begin{abstract}
A Major Research Paper
presented to Ryerson University

In partial fulfilment of the requirements for the degree of

Master of Arts, in the program of Immigration and Settlement Studies
\end{abstract}

Toronto ON Canada, 2019

C) Sugandha Chatterjee 2019 


\section{AUTHOR'S DECLARATION FOR ELECTRONIC SUBMISSION OF A MAJOR RESEARCH PAPER (MRP):}

I hereby declare that I am the sole author of this MRP. This is a true copy of the MRP, including any required final revisions.

I authorize Ryerson University to lend this MRP to other institutions or individuals for scholarly research.

I further authorize Ryerson University to reproduce this MRP by photocopying or by other means, in total or in part, at the request of other institutions or individuals for scholarly research.

I understand that my MRP may be made electronically available to the public.

- Sugandha Chatterjee 
RE-EMERGENCE OF PAPER MARRIAGE DISCOURSE AS IMMIGRATION FRAUD

\author{
Sugandha Chatterjee \\ Master of Arts, Immigration and Settlement Studies, 2019 \\ Ryerson University
}

\begin{abstract}
:
This paper examines marriage fraud to bypass immigration restrictions. It assesses media representations of marriage fraud for the purpose of immigration in Canada and Germany between 2000-2019. Paper marriages refer to a marriage which is not bonafide but is done to get residency status in a country by at least one of the partners. In this study, I will examine the media's role as an agency that both shapes and reflect public opinion on this issue. I am interested in understanding what led to the rise of the discourse of paper marriages? Is this an attempt to bypass tightening of immigration rules, or is it because of the rising tide of xenophobia and distrust to foreigners? I will also examine two competing perspectives on paper marriages. The first approach looks negatively and sees paper marriages as a form of deceit or fraud. The other, takes a more compassionate perspective and sees it as an attempt to help others gain residency status. I will examine the role of the media as a moral entrepreneur in creating "moral panic" about immigration fraud.
\end{abstract}

Keywords: Paper marriages, marriage migration, marriages of convenience, marriage fraud, moral panic, moral entrepreneurs, opinion leaders. 


\section{Acknowledgments:}

I wish to thank my parents, who had faith in me, their crazy daughter, who just wants to accumulate degrees.

I want to thank my partner for taking care of our four puppies and the whole household for three months by himself while I was in Germany and enjoying Europe.

I want to thank Mitacs Globalink Award, and especially Leslie and Twinkle, for all their help in procuring the award money, the only way I could afford my stay in Germany for the three months.

I want to thank Dr. Antonie Schmitz, my exchange co-ordinator and supervisor in Germany for her key insights and helpful suggestions.

I want to thank Dr. John Isbister for his helpful insight and time on reading my paper. I was so lucky to get you as my second reader.

Foremost, I want to thank Dr. Mustafa Koc, my MRP supervisor, for all his patience and his generous allotment of time, and the ton of signatures that were required for this MRP and my exchange trip to Germany. I want to thank him for bearing with me and supporting me when I was at my lowest, for his ever-encouraging words and his introduction of this topic to me. Without you, Professor, this would not happen.

- Sugandha Chatterjee 


\section{Table of Contents:}

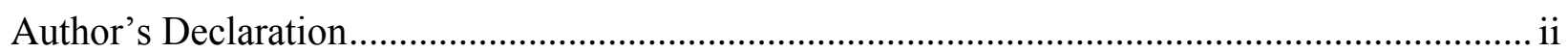

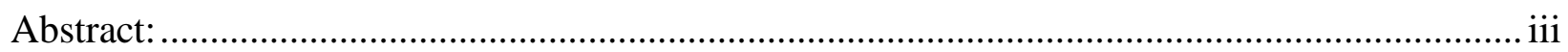

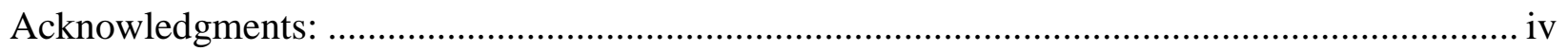

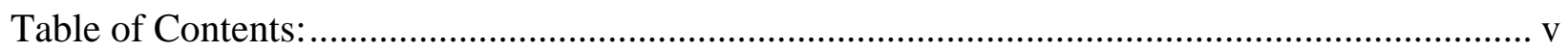

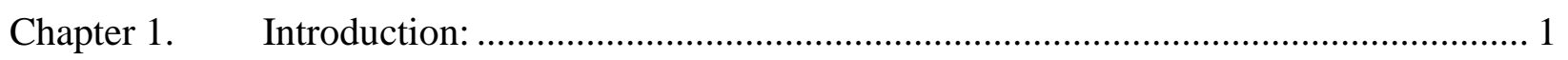

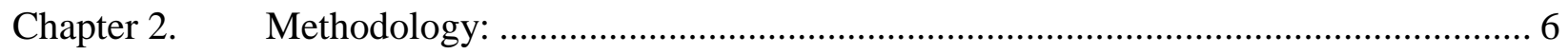

Chapter 3. Theoretical Frameworks:............................................................................ 12

Chapter 4. Paper Marriages and Immigration: ......................................................... 21

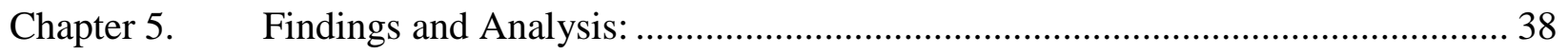

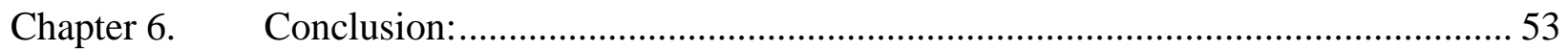

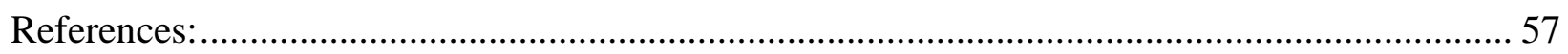




\section{Chapter 1. Introduction:}

Print media, especially newspapers, have traditionally played a role in educating public and shaping public opinion (Nancy, 2018). They are the watchdogs of our society and alert the public to possible threats and trends (Dominick, 2002). They also shape readers' understanding of themselves and their world. Newspapers play an important role in funneling information about the issues that public seek knowledge and information about, and contribute to the formation of public opinion (Happer \& Philo, 2013). .

In this paper I will examine how media treats marriage fraud for the purpose of immigration in a small sample of German and Canadian newspapers. Using the concepts of "moral entrepreneurs" and "moral panic", I will examine media's role in sensationalizing this topic and in shaping public opinion. Moral panic refers to "a condition, episode, person, or group of persons" defines "a threat to societal values and interests" (Cohen, 2011, p. 9). "Moral entrepreneurs' on the other hand refers to an individual, group or formal organization that aims to influence a group to adopt or maintain a norm (Cohen, 2011). Media has become one of the key institutions in the modern era that acts as a moral entrepreneur and can be responsible for the creation of moral panics (KhosraviNik, 2010; Herman \& Chomsky, 2010).

In recent years, the stories of marriage fraud for the purpose of immigration has preoccupied government authorities, the reflection of which is also seen in the media. My intention is to examine how newspapers in immigrant receiving countries have responded to this issue and what their roles were in shaping public opinion. There are several terms used in reference to marriage fraud, such as marriages of convenience, sham marriages, fake marriages, etc. While this discourse has a negative connotation of deception, I will also examine an 
alternative and more sympathetic discourse that calls these marriages mainly as 'protection marriages' or marriage for solidarity. In this paper I will use the term "paper marriages", broadly to refer to the discourses of immigration fraud through marriage, both the positive and the negative.

I want to understand how we moved from a recognition of family reunification as a human right defined by the Universal Declaration of Human Rights which states: "Men and women of full age, without any limitation due to race, nationality or religion, have the right to marry and to found a family. They are entitled to equal rights as to marriage, during marriage and at its dissolution" (The United Nations, 1948, para 1); to a discourse of paper marriages as a fraud. Is it because there is a phenomenal rise in paper marriages, or is this a response to the tightening of immigration rules regarding family reunification? Are these queue jumpers, or are they people trying marriage as a last ditch effort to by-pass a tightening immigration regime? I would also like to know what role the media has been playing in shaping public opinion towards paper marriages.

In this study, I will examine how do Canadian and German immigration authorities determine if a marriage commitment is genuine or not. I am also curious to determine if there are regional, ethnic, and racial differences in cases identified as marriage fraud. Initially, I planned to do several interviews among couple who went through the experience of applying for immigration through family reunification process. However, time limitations and challenges of receiving ethics clearance on time to complete the paper in the limited time frame of three months, made me change my focus on to the question of the role of the media representations of paper marriages in Germany and Canada. The reason, I chose to do media analysis through newspapers in these two countries was because, I wanted to identify the key messages and their 
framing to systematically understand, what the public has been consuming and what shapes their value judgements in the two countries. The objective of this paper is to examine whether the newspapers and press releases are fuelling and causing moral panics amongst the residents of Canada and Germany, in regards to the extent of paper marriages in these countries.

This paper is divided into six chapters. Following this introduction chapter, in Chapter 2, Methodology, I discuss the scope of this paper, specifically the whys and wherefores of my choices of Canada and Germany, along with their specific family reunification programs. The temporal scope of 2000-present is then justified for my research, which is in brief, to study the current trends and the current developments of the phenomenon of paper marriage. I further give the reasons for choosing the specific newspapers from Canada and Germany. The newspaper's political leanings, their fact-check quality, ease of access in English language were some of the key considerations that led to the choice of those papers. This chapter further discusses the methodology of critical discourse analysis used for this paper. This was done to study the linguistics of the columns and the word choices as presented to the public, to see if they indeed followed the trajectory of Goode \& Ben-Yehuda, (1994)'s attributional model that resulted in ballooning of the phenomenon of paper marriages into a moral panic.

In Chapter 3, Theoretical Frameworks, I do a thorough review of the literature on theories of immigration, migrant marriages, media and public opinion, along with theories of moral entrepreneurs and moral panic. The concepts of gatekeepers and fencers are discussed in relations to the authorities that are responsible for allowing and selecting which immigrants gets in the country and which are kept out, or removed from the country. The moral panic theory is used to figure out whether the phenomenon of paper marriages can be declared a moral panic and whether its falls into the socially constructed definition of deviance. By looking at the media 
discourse from 2000-2019, I intend to test the phenomenon of paper marriage against the qualifiers or the themes of moral panic of the attributional model as given by Goode \& BenYehuda (1994); namely, volatility, hostility, measurable concern, consensus, and disproportionality. Furthermore, paper marriage if declared a moral panic is then tested against the defintitions of good moral panic as given by Hier (2016). I will then test how the media discourse and various press releases are creating a 'good' type of moral panic amongst the people who support 'open borders' and an individual's right to live safely and get better opportunities in their lives. This will be done by critically analyzing the discourse against the qualifiers of compassion, care and social obligations as given by Hier (2016), to be considered that the phenomenon is developing into good moral panic.

In Chapter 4, Paper Marriages and Immigration, I explore the interrelations between paper marriages and immigration. The history of migrant marriages, along with the type of people who may potentially enter into paper marriages are discussed. In charged political environments like what we have in our contemporary times, it becomes easy to inflate a nonissue into disproportionate sizes and create moral panics amongst the locals as has been seen in both the USA (with Trump), and the UK (with Brexit). The moral panic has taken the shape of 'panic-as-regulation' (Hier, 2019) in these countries. Although the situation is improving slightly at the time of this study, the literature suggests, it had done the same in Canada in the early $21^{\text {st }}$ century (Gaucher, 2014). Moreover, it is doing the same in Germany now (Europol, 2018). This then points us to the direction that the tightening immigration control could actually be a result of xenophobia and distrust of the foreigners. Next, marriage for solidarity and the associated underground movement rising in Germany is deliberated about. Furthermore, the 
discourse on 'illegal' migrants as presented by the media and how it shapes the public opinion is taken into consideration.

In Chapter 5, Findings and Analysis, we inspect the case of paper marriage as moral panic. Migrant marriages and the increased securitization and belief that most migrant marriages are paper marriages have been presented by the politicians as a threat to the moral order of the sacred institution of marriage (Benson \& Charsley, 2015). Governments in many immigrantreceiving countries are adopting what is defined as 'technologies of love', described as "central to the governmentality of marriage migration; as modes of subjectification and governing practice, they connect intimacy with citizenship. [..] technologies of love play a significant role in stirring and disciplining specific migration flows (what kind of marriage migrant the state welcomes or keeps at bay)" (D'Aoust, 2013, p. 258). Under the technologies of love, the governments of immigrant-receiving countries often equate their understanding of marriage as the normalized version and use that as a gatekeeping tool (Pellander, 2015). Gathering evidence from the print media discourses; press releases; government notices; parliamentary debates; and policy papers, this study, looks into how the public is presented with the discourse of paper marriages. This study further examines the media's role as an agency, both shaping and reflecting public opinion. The analysis covers newspaper articles from The Globe and Mail, Toronto Sun, and CBC newspapers from Canada and Spiegel newspaper and The Local Germany newsfeed from Germany. The analysis also covers press releases from Europol, CIC (IRCC) and CBSA, to find the prevalent themes in the newspapers and press releases. This analysis was used to determine whether the opinion leaders present this phenomenon of paper marriages as symptomatic of moral panic. The government notices; policy documents; and parliamentary debates, published after the year 2000, is used to analyze the migrant marriage gateway, and how 
it has evolved since 2000 in the two countries. This analysis is then used to qualify the moral panic as a good moral panic (Hier, 2019; McLaughlin, 2014; Young, 1971).

Following the above, is Chapter 6, Conclusion. This chapter concludes the paper, and provides the limitation of this research.

What attracted my attention to this topic is also, partly based on my personal experience as an immigrant woman from India with a partner from El Salvador. We are common-law partners as defined by Canadian legislation and have been for the past four years. We are both permanent residents in Canada. My partner came to Canada as a refugee claimant twenty-five years ago. I came to Canada as an international student on a student visa seven years ago. After five years in Canada on a temporary visa, I finally became a permanent resident through economic class last year. My partner had the option to sponsor me, but both of us chose not to go that route. I suspected that my legitimate relationship would not have passed the immigration fraud test if my partner would have applied for my spousal sponsorship. I worried that immigration authorities might be biased towards a visible minority woman and look at my application as a sponsored partner with suspicion.

\section{Chapter 2. Methodology:}

This chapter starts with the scope of this study, i.e., the countries involved, the time period, and the sourcing of the data. The word choices and linguistics surrounding the phenomenon makes for the most interesting analysis of the opposite teams, i.e., the politicians, newspapers, and anti-immigrants, vs. the activists and border artists. Hence, critical discourse analysis was the method selected for this study. DeepL Pro, an AI translation technology, is used to translate the contents of German sources into English. 


\subsection{Scope of this Study:}

This study would have a temporal focus from 2000 to present. Although this issue has been a concern for immigration authorities since the beginning of the $20^{\text {th }}$ Century, there has been an increasing tendency for controlling and restricting marriage from the global south to the advanced industrial countries of the West in recent decades. By focusing on the first two decades of the $21^{\text {st }}$ Century, I wanted to capture some of the most current leanings. This time period, is also interesting because of the many political changes that happened during this time frame in both Canada and Germany as defined below.

The focus areas geographically are in Canada and Germany. The reason for this focus is mainly because of my geographical location and ease of access to data in Canada, where I live, and Germany, where I traveled as an exchange student in May-July 2019, where I wrote the majority of this paper. These two very different geographical locations are also interesting as the politics of the two countries are also quite different at the moment. While Canada, before the current liberal government, had a strong focus on anti-immigrant approach, it has adopted a more pro-immigrant attitude under this liberal government. The new government removed antiimmigrant legislation, 'conditional permanent residency'. The timeline for family sponsorship was cut down to under twelve months. And, the time required to become a Canadian citizen, after receiving permanent residency status was also lowered. In Germany, on the other hand, under Angela Merkel's "leadership, the conservatives have not only adopted a welcoming stance toward refugees but also come to see immigration as crucial to Germany's future - even if a slight majority still resists the idea of dual citizenship." (Chase, 2017, para. 5). Germany; however, under the Dublin III agreement, also deported 8,658 asylum seekers to other parts of EU in 2018, this number the year before was 7,102 (Bielecki, 2019). 
Both Canada and Germany are also immigrant-receiving industrialized countries, with strong economies. There has been numerous studies done on the topic of marriage migration for many immigrant-receiving countries (Wray, 2011; Yuval-Davis, Wemyss, \& Cassidy, 2018; Pellander, 2015; Kim, 2010; KhosraviNik, 2010; Infantino, 2014; Fassin \& Salcedo, 2015; Eggeb $\varnothing, 2013$; Benson \& Charsley, 2015), but very few have dealt with Canada and Germany per se. (See, for example, Gaucher, 2014; Dullabh, 2013; Kreienbrink \& Ruhl, 2007; Qu, 2016). The two countries also have immigration programs that are explicitly designed to reunite families. Both countries have been attracting a significantly high number of immigrants in the post-World War II era. It can; however, take a long time, financial resources, and other qualifications to be able to gain an immigrant status in these countries. These qualifications, or restrictions rather, on who gets in, can cause people who want to live in Canada, but cannot qualify themselves, find illicit ways to enter or remain in the country (Beck-Gernsheim, 2011). For Germany, since it is part of the European Union, the cases are different. Being a member country allows for free movement of people in the European Union; however, for people from non-member countries of origin, obtaining residency status can be difficult. Both these countries currently; however, have a strong emphasis on family reunification. They have special immigration programs that specifically cater to the same. These programs are described below:

For Canada, the Family Reunification Program (FRP) has always been a priority. It is considered as one of the three pillars of IRCC's (formerly CIC) immigration programs (Evaluation Division, 2014). Immigration and Refugee Protection Regulations (IRPR), under the FRP, warrants that citizens and permanent residents can sponsor their family members including spouses, common-law partner, conjugal partners, dependent children, parents and grandparents to Canada (Evaluation Division, 2014). Although, the evaluation of this program has revealed 
that attempted fraud and misuse of this program, especially in the spouse and partner category, is high; the extent of the abuse has not been able to be determined due to lack of relevant data collected by IRCC (Evaluation Division, 2014).

Germany's Family Reunification (FR), works in two ways, depending on where the foreign spouse is from. If the spouse is a citizen of the EU, then they are governed by the right of free movement. If the spouse is from a third country (not an EU member), they are governed by the Family Reunification Directive of 2003, Union Citizens Directive of 2004, and Residence Act of 2004 in Germany (Kreienbrink \& Ruhl, 2007). A person who is a citizen of another EU country (EU Blue card holder) can also sponsor their partner in Germany, if they can prove that the sponsorer works in Germany and has a primary residence there (Kreienbrink \& Ruhl, 2007).

For this study, multiple sources of data were used. The analysis covers newspaper articles from 2000- present of three major Canadian newspapers; namely, The Globe and Mail (14), which has a moderately conservative ideology; Toronto Sun (8), which has conservative ideology; and $C B C(15)$ with moderately liberals bias. From Germany, Spiegel (9), a moderately liberal newspaper, and The Local Germany (9), a liberal newsfeed were covered (Media Bias Fact Check LLC, 2019). Except for Toronto Sun, which has reasonable fact-checking standards and is a sister body of other PostMedia newspapers like Calgary Sun, Ottawa Sun, and Montreal Sun, all the other newspapers were selected for their high fact check standards and online availability. A proper conservative newspaper for Germany, i.e., Frankfurter Allgemeine Zeitung was not an option because it was not a newspaper that was available for free online. Furthermore, this study used a number of press releases from Europol (5), Citizenship and Immigration Canada (CIC)/ Immigration, Refugee and Citizenship Canada (IRCC) (3) and Canada Border Services Agency (CBSA) (2), to find the prevalent themes in the newspapers and press releases 
to do the critical discourse analysis. The government notices (4); policy documents (3); and parliamentary debates (3), published after the year 2000, is used to do a comparative content analysis in the two countries. Although it would benefit this study greatly, due to time constraints it was not feasible to conduct interviews with individuals. A study with primary data collection analysis could be a part of future research.

\subsection{Critical Discourse Analysis:}

This study uses critical discourse analysis (CDA) to study the themes that have emerged in the policy documents and the newspaper between 2000-2019 in the Canada and Germany. CDA is defined as "the general label for a special approach to the study of text and talk, emerging from critical linguistics, critical semiotics and in general from a socio-politically conscious and oppositional way of investigating language, discourse, and communication" (van Dijk, 1995, p. 17). A language is a potent tool, used by the politicians and the newspaper to gently nudge people towards their ideology. Newspapers often "publish factual information that utilizes loaded words (wording that attempts to influence an audience by using appeal to emotion or stereotypes) to favor [their] causes” (Media Bias Fact Check LLC, 2019, para. 1).

CDA is then applied to the limited data sources in the context of paper marriages in the gray literature that is gaining some grounds amongst the activists and border artists. This study tests for the themes or qualifiers of moral panic that gets presented in the narratives about paper marriages in the press releases and the newspapers, and amongst the activists. The themes are then analyzed to determine if the phenomenon of paper marriages is actually normatively ambivalent and is effectively helping cause social reactions that "buttress hegemonic understandings of, and moral responsiveness to, violence, injustice, suffering, and harm" (Hier, 
2016, p. 867). This is done by testing the linguistics presented in newspaper articles against the themes of compassion, care and social obligations. Thus, concluding if the phenomenon of paper marriages has reached a level of moral panic that is now evolving into a good moral panic.

\subsection{Methodology - Conclusion:}

This study will use critical discourse analysis to examine media representations of immigration fraud in Canadian and German newspapers. It also uses notices, policy documents, scholarly research, and parliamentary documents, along with press releases, to generate prevalent themes in the discourse of paper marriages since 2000. The attributional model of Goode \& BenYehuda, (1994) provides us with five qualifiers of moral panics, i.e., if the linguistics and the presentation of a phenomenon follows the five qualifiers of 'volatility', 'hostility', 'measureable concern', 'consensus', and 'disproportionality', I conclude, that the media is presenting the phenomenon as a moral panic now. If the presentation of the phenomenon adopts the themes of 'compassion', 'care', and 'social obligation', the phenomenon is developing into a 'good' moral panic as given by Hier (2016). I would; however, refrain from making value judgments on what can and should qualify as 'good' or 'bad' moral panic. Should the phenomenon of paper marriage show the attributes of both Goode and Ben-Yehuda's attributional model, and Hier's good moral panic model, I would conclude that the phenomenon has reached a level of moral panic, where the masses are presented with full 360-degree view or the complete picture of the phenomenon and the public can then make their own decision on which side of the argument do they stand with. 


\section{Chapter 3. Theoretical Frameworks:}

This chapter provides a review of the analytical frameworks that sets the study's tone in the critical discourse analysis of the social construction of borders (Yuval-Davis, Wemyss, \& Cassidy, 2018), representation of refugees, asylum seekers and immigrants in the media (KhosraviNik, 2010), moral panic (Cohen, 2011; Hier, 2016, Goode \& Ben-Yehuda, 1994) and 'gatekeeping' and 'fencing' (Triandafyllidou \& Ambrosini, 2011)

\subsection{Immigration, state regulation, and border controls:}

Social inequality is a phenomenon that has become widespread in current times. The gap between the poor and the rich nations have become insurmountable. While some people live a relatively harmonious and safe life, the others are destitute, living in a dangerous political and economic space. In the age of globalization; however, where the distances are compact and the world is more accessible, people capable of improving their living standards do so in the form of migration (Beck-Gernsheim, 2011). Worldwide media gives a glimpse of a possibility of what life could be, to many, in a safer, more stable country (Appadurai, 1991). Global tourism has a similar impact in giving hopes to many, of a better life elsewhere (Lash \& Urry, 2007). Global integration, have compelled many to question, "why be poor and repressed here when people elsewhere have plenty to eat, own a house and car, and can go to the doctor when they fall ill? Why suffer here? Why not try to go there?" (Beck-Gernsheim, 2011, p. 62).

There are diverse explanations about why people migrate. While some focus on push and pull factors such as better wages (Ravenstein, 1889) or better job opportunities (Todaro, 1969), others refer to improved life and socio-economic status of their family (Stark \& Bloom, 1985); or 
following the path of family or friends (David, 1998). Alternatively, it could be because they fear for their family's and their safety (Massey, 1990).

Many first-world countries; however, are now closing their doors to economic migration and asylum seekers, and putting in tighter controls (Yuval-Davis, Wemyss, \& Cassidy, 2017; Triandafyllidou \& Ambrosini, 2011). However, as Bledsoe (2004) writes, “[c]reating policies inevitably creates the potential for actions that contravene these policies" (p. 97). Prospective migrants, thus, try to find loopholes in the policies to secure their possibility of a better future. These loopholes are then corrected by the authorities, turning this process into a 'cat-and-mouse game' (Palriwala \& Uberoi, 2008; Beck-Gernsheim, 2011). Beck (2006), says by not accepting the immigration rules set by the authorities at face value, and using them as devices for strategic actions, the potential immigrants and the sympathizers of the cause of open-borders, learn to manage the borders by becoming 'border-artists'. "Knowing when to keep clear of borders and when to cross them, how to subvert, circumvent, bridge or make use of borders, all the while carefully adapting to context, situation and moment” (Beck-Gernsheim, 2011, p. 62). Strategies like 'biography management' (Bledsoe, 2004), 'education for leaving' (Fleischer, 2007), 'sporting education' (Walt, 2008), and 'marriage migration' are mentioned as varieties of border management strategies

Generally, for a person who wishes to migrate, there are four options: apply for the economic class; seek asylum; take illegal route; or apply for the right to family reunification (Beck-Gernsheim, 2011). Thus, for someone who does not find themselves eligible for the first two options, the illegal route or family reunification are the only options left to get to the country and the life that they truly want. If a country's immigration policies do not support the person's 
claim to seek residency, that very reason could stand for why that individual would go to the extra length of defrauding the system to gain access or live in that country.

\subsection{Family Reunification and Marriage Migration:}

Marriage in the pre-industrial time was an essential part of the family economy and was used strategically to build alliances and improve family status. Marriages for expansion of kingdoms, or religion, or gaining allies, were only too common in Europe and Asia till the $18^{\text {th }}$ century. Only in later $18^{\text {th }}$ and the $19^{\text {th }}$ century have marriage become synonymous to romantic love in the western world, even though the pre-industrial patterns are still followed in other parts of the world. Globalization and marriage migration have become instrumental to people trying to improve their family standing. As the economic and political climate in many parts of the world deteriorates, people wish to immigrate for better opportunities. With stricter rules and more restrictions imposed by the western world on immigration; however, people are finding marriage migration as one of their only chances at better prospects and live in a country that they desire (Beck-Gernsheim, 2011).

Marriage migration is seen as a threat to regulate population movements and border controls by politicians, bureaucrats and people who are against immigration (Böcker, 1994). As they express their concerns, these are picked up by the media as news stories and important commentaries and presented to the public. Media representations lead many to confuse the phenomenon of marriage migration with that of paper marriages, mail-order-bride, forced marriages and sex-trafficking often leading to negative stereotyping of people involved in marriage migration, i.e., cross-national or binational marriages (Williams, 2010). This confusion leads to increasing bias towards marriage migrants as deviants and their marriages as fraudulent 
acts, which often result in higher levels of scrutiny, delays and rejections in application of family reunion requests. This negative stereotyping also feeds into the discrimination and othering of immigrants, sometimes referred to as 'outgroups', especially racialized women, who are thought of as victims/ opportunists, and racialized men as the moral deviants who wish to corrupt the naïve native women of the immigrant-receiving countries (Cadman, 2015). Here, the family life or rather who and what forms the family is guided by the immigration regulation (Strasser, Kraler, Bonjour, \& Bilger, 2009). The process of keeping the people who do not 'belong', is called 'moral gatekeeping' (Wray, 2011; Eggebø, 2013). Canada and Germany also use 'fencing' defined as actively tracking, arresting, and deporting the 'illegal' migrants (Triandafyllidou \& Ambrosini, 2011). People convicted of paper marriages in both countries are subjected to deportation, fines, and/ or imprisonment (Alkousaa, 2017; Canada.gc, 2019; Europol, 2017; Quan, 2016).

Timmerman (2008), calls the "persistently high popularity of migration marriages within large immigrant populations an intriguing phenomenon" (p. 585), referring to the persistent choice of the spouse of second-generation Turkish migrants residing in Belgium, from Turkey. This phenomenon is also seen in the Indian and the Chinese populations residing in Canada (Somers, 2015). Scholars have argued that marriage migration often is the result of positive assortative matching (PAM), getting married for a better prospect for oneself and his/her family (Çelikaksoy, Skyt Nielsen, \& Verner, 2004). Although paper marriages are also a type of PAM, it is not the only type. A concept of marriage migration 'from below', explains this concept as, marriage as a tool, in an unequal world, with limited opportunities to move from more inadequate to more affluent countries (Beck-Gernsheim, 2011). 
Wray (2015), describes four broad categories of marriages that may result in the formation of migrant marriages. She argues that only one type is what can be construed as a real paper marriage, i.e., a marriage conducted solely for gaining immigration in a country. However, Wray (2015), also says that other categories are often targeted by the 'gatekeepers' to examine their genuineness. One of the categories, she claims is the one with arranged marriages. Marriages like this would have marital attributes like cohabitation, but the suspicion lies that without the perceived advantage of a better country, this marriage would not happen. The hardship of refusal is often thought of as insignificant in arranged marriage cases because of no previous relation. However, this fails to take into account the hardship caused by loss of family assets, cultural values, and losing face in case, the marriage is labeled as fake by the immigrantreceiving country (Jimenez, 2018; John, 2010). The second category is that of 'opportunistic' marriages or unilateral paper marriages or marriage gris. In this category, there is a deception by the immigrant spouse who gets involved in a physical relationship and may even have children with their partner but leaves as soon as the immigration documents are received. A gender dimension of an older naïve woman with younger 'deviant' men is often associated with this category (Wray, 2015; Cadman, 2015; Bonjour \& De Hart, 2013). The third category of marriage migration has zero consideration of migration. It merely is between two people in love who rather than living in two separate parts of the world, wish to stay together and hence marry quickly in a perhaps small intimate ceremony. They then migrate to a country that offers the best opportunities socially and economically for their future family. These couples depending on the country of origin, are treated as the opportunistic kind, if their countries of origins are not economically at par with each other, and their residency requests denied (Charsley \& Benson, 2012). The fourth category of the marriage migrants are relatively rare and rarely face the 
scrutiny that the other three categories face. In this category, the country of origin vs. the country of destination theory comes into play (Jennissen, 2004; Fleischmann \& Dronkers, 2010). The sponsored spouse is from a wealthy or a comparable nation like the USA, the UK, Australia, South Africa and similar, and thus are accorded more leniency by the immigration authorities. This unique treatment presents the proof of discrimination and assumed guilty verdict for immigrants from 'countries of suspicion' (Gaucher, 2014). It then points out that individual characteristics of a potential marriage migrant are on trial and not the characteristics of the marriage (Wray, 2015).

Attitudes of politicians, policy makers and immigration authorities towards paper marriages and reflection of these perspectives in the media, makes us question the role of media as a gatekeeper. What appears as news is not only providing information to public but is also shaping their perspectives. In this sense, a review of the theories of moral panic would be helpful.

\subsection{Theory of Moral Panic:}

Moral Panic Theory was first introduced by McLuhan (1967) as a form of public overreactions that are socially regressive. McLuhan (1967) said that irreversible developments in media were fuelled by 'deviance implosion' that fuelled moral panic in the masses. He said that cultural elites were obsessed and fascinated by anything that had the capability of causing 'moral panic' and angst. McLuhan identified 'alarm', 'resistance', and 'exhaustion' as the three stages of panic that were fuelled by media reaction (McLaughlin, 2014).

Since the 1980s, moral panic was recast as a moral regulation (Hier, 2019). In a political environment of "authoritarianism" from above and "disaffection" from below, moral panics play 
a role in moral regulation "by locating market-oriented subjectivities in the wider trajectory of neoliberalism". According to Hier, this achieves "two things: first, a clearer understanding of the normative phase of neoliberal rule in whose image the panic-as-regulation perspective is crafted; second, a stronger position to develop insights into post-hegemonic claims-making activities that are appearing across the political and cultural spectrums" (2019, p. 2-3). Arat-Koc (1999), argues that Canadian immigration policies, since the 1990s, have been increasingly neoliberal in nature. This has been the case, especially with more restrictive laws and procedures for family sponsorships.

Hier (2016) and Cohen (2011); however, argue that there could be 'good moral panics' as well. Hier (2016), states that "In contrast to the tacit scholarly consensus that moral panics entail regressively conservative social reactions to putative harms, moral panics are alternatively conceptualized as normatively ambivalent operations of power" (p. 867). This 'operations of powers' then becomes the tool to stand against the regressive societal norms that may have been resulted because of the declared moral panic. Cohen (1999)'s, interests in 'good' moral panic showed how the original 'bad' moral panics are sometimes used by the activists and moral entrepreneurs to work towards stopping the cruelty and sufferings against humans. Hier (2016), says that by "reversing the norms of intelligibility," (p. 867), a part of the society responds by correcting the "violence, injustice, suffering and harm" (p. 867) against fellow humans. Cohen (2011), states that by categorizing an activity or a phenomenon as a moral panic, sociologists are denouncing "claims about putative problems as exaggerated representations that hide more than they reveal about actually existing threats" (as cited in Hier (2016: para.3)). This phenomenon, Cohen (2011) claims, could hurt society more if the label of moral panic is attached to it. Welch (2006)'s paper describing post - 9/11 America tells about the many human rights violations that 
happened against the Muslim community because of the moral panic that was created. Hier (2016), demonstrates how caring relations and social obligations represent coexisting forms of responsibility that complement, compete with, and potentially contradict forms of entrepreneurial subjectivity" (p. 869). His argument stands that 'good' moral panics are created often in response to the 'bad' moral panic that are regressive and targets certain minority groups. $\mathrm{He}$ conceptualizes moral panic as "normatively ambivalent operations of power that derive both from conservatively regressive social reactions to putative harms and liberally progressive relations of compassion, care, and social obligation that can be both fleeting and circumscribed" (p. 870). Thus, according to Hier's definition, the moral panic on paper marriages can be considered as reaching or developing into a 'good' moral panic if the themes of compassion, care and social obligations are each observed in its making. Cohen (2001), infact advocated for the spread of 'good' moral panic in response to societal injustices. For him, the good moral panic is "a human rights imperative oriented towards exposing, disrupting, and reversing the cognitive, emotional, and cultural mechanisms of denial that thwart unfettered recognition of violence, atrocity, suffering, and injustice" (as cited in Hier, 2016, p. 868).

This study thus aims to understand, whether the moral panic about the whole issue of paper marriages in Canada and Germany which is fueled by the print media has developed into 'good' or still remains with the conservative viewpoint. Hier (2016)'s paper on 'good moral panic' is although very interesting and provides a positive view to a problem, it must also be observed critically. Good and bad are both subjective value judgements, and to declare moral panics associated with liberal values as good and the ones associated with conservative viewpoints as bad, could be construed as a blanket statement, which is not the point of this study. Thus, if the phenomenon of paper marriage is determined to show symptoms of bad moral panics 
given by Goode \& Ben-Yehuda (1994), and of good moral panic as given by Hier (2016), the study would declare that the phenomenon has reached a 360-degree view of moral panic and is now providing the public with choices from both ends of the spectrum to make their own judgments. To do that, this study would analyze the moral panic about paper marriages by drawing parallels from the study of Victor (1998), on 'Moral panics and the social construction of deviant behavior, a theory and application to the case of ritual child abuse'. The study then determines whether the moral deviants, in this case, people who get into paper marriages, are a contemporary legend (Ellis, 1990) and whether the moral entrepreneurs in the newspapers are using exaggerated claim-making in fueling the moral panic. This would be done by analyzing the content of claims such as whether there is a focus on stereotypes of deviants and their behaviors, if there exists a typology of the variation in behavior of these deviants, whether the opinion leaders are providing description of dangers and harms that these deviants are causing the society or can cause a member of society in this case, and if there are rationales that provide ways of dealing with these deviants (Victor, 1998).

The moral panic theory looks at the phenomenon of paper marriage from an outsider's perspective. This deals with the perceived reaction or overreaction of the people to the phenomenon of paper marriages. While the moral entrepreneurs frame their arguments using normative ethical arguments; the people who believe that the phenomenon of paper marriages and its extent is blown out of proportion uses empirical evidence to support their case (Buchanan, Shaw, Ford, \& Singer, 2003). 


\subsection{Theoretical Frameworks - Conclusion:}

Marriage as a migration strategy is gaining importance worldwide and becoming problematic to the securitization of a nation as presented by media and the politicians. The covert racism and discrimination along with the underlying assumptions of what a nation and its people should behave gave rise to the concepts of 'pure relationship', 'folk devils', 'deviants' and 'moral gatekeepers', etc., to come up in the immigration and the media studies. Anti-immigrant sentiments take a rise when immigrants are presented in a bad light by the media and the politicians. One of the causes of the anti-immigrant phenomenon is happening through the discourses surrounding the extend of paper marriages. The analytical framework developed in this chapter decides; however, if the phenomenon of paper marriage is indeed a moral panic. This would be done if it meets the five indicators of moral panic given in the attributional model (Goode \& Ben-Yehuda, 1994). Next, whether the phenomenon of paper marriages is morphing as 'good moral panic' as given by Hier (2016), would be tested by the three 'good moral panic indicators'.

\section{Chapter 4. Paper Marriages and Immigration:}

This chapter contains a brief historical and analytical insights from the existing body of literature on how paper marriages came into the forefront of immigration and media studies. The chapter continues with the media representation of the 'illegal' immigrants, the prospective participants in paper marriages, the rising underground movement of solidarity that supports paper marriages, and finally the media and moral panic about paper marriages with a case study focus on Canada and Germany. 
Immigration flows to the Global West have been happening for a long time from both Global South and from the post-colonial countries. Stark \& Bloom (1985), state that people move from one country to another seeking better prospects economically for themselves, and their families (Stark, 1991; Massey et al, 1993). Other people migrate in search of a safe haven or due to forced migration. The perceived benefits of living in a particular country sometimes are so attractive, that some people would willingly take illicit routes to gain status in that country, including that of getting into a paper marriage. This action, as some would put it is, not a marriage of convenience but a marriage of necessity (Weaver \& Trevino, 1994).

The historical concept of 'paper families' are currently taking a new form in the shape of paper marriages. This form, unfortunately, is not that uncommon as is often presented by various institutes, newspapers, and some scholars (Evaluation Division, 2014; Asllani, 2016; BBC, 2017; CIC News, 2017; Cadman, 2015). Scholars have described two primary forms of paper marriages. First, where both parties are aware of the fraudulent nature of the arrangement and get into the paper marriage willingly, i.e. contractual paper marriage (Dullabh, 2013; John, 2010; De Armas, 2007). In this case, most often one of the parties is a citizen or in some cases, permanent resident of the immigrant-receiving country. They marry a foreigner out of compassion, or because they feel they are socially obligated to do so. Or on other occasions in exchange for monetary gain or other personal gains (North, 2016). An example of this is the well-known case of Kiril Hristov Vidinski, a Bulgarian born man who married a US citizen and paid her $\$ 5,000$ to gain a green card (North, 2016). The price associated with this type of paper marriages varies by host countries and between communities (Abrams, 2012). Some of these contracts are time-based as seen in the example given by Cuen (2016), of Steve and Tiffany, where Tiffany was paid $\$ 10,000$ upfront, $\$ 15,000$ after two years and another $\$ 5,000$ after 10 
years of Steve receiving his USA green card (Cuen, 2016). The second form of paper marriages is when one of the parties involved is a victim of fraud and is unaware of the intentions of the other individual, i.e., unilateral paper marriage. This type of paper marriage can also be explained by the Social Exchange Theory; however, the exchange here is of love and following residency status between the partners and is committed by deceit by the latter partner. The victims most often are a citizen or a permanent resident of the immigrant-receiving country (Dullabh, 2013; John, 2010; Cadman, 2015; De Armas, 2007). This individual is fooled into falling in love with a person whose sole purpose is to gain immigrant status through spousal sponsorship (Cadman, 2015). Sometimes, this second form of paper marriages also results in abuse and assault (Meurrens, 2017; Brown, 2015). Other times; however, the victim could be the foreigner who is then abused by their partner to stay in that relationship for fear of deportation (Wang, 2013).

Some researchers (Abrams, 2012; Asllani, 2016; Dullabh, 2013) believe that in the twentieth century, policies were developed in many immigrant-receiving countries that tied public benefits like welfare assistance, food stamps, housing, etc., to marriages. These public benefits, then act as pull factors, as explained by Todaro's theory of migration as the reasons that pull a person to a host country (Chen, 1994), and for people to get into paper marriages (Abrams, 2012; Dullabh, 2013). Other researchers believed that the push factors from the home countries are so significant for some immigrants that it drove them to go to fraudulent means to gain status in host countries. Some of these factors included safety issues, while others included economic issues (Kwok, 2019; Myall, 2019). Other times the immigration policies in receiving countries were so strict or exclusionary, that the potential immigrants found themselves with no other options but to fake a marriage (Kwok, 2019). On other occasions, getting a sponsorship meant 
the status was granted much faster than any other immigration gateway (Abrams, 2012). If any of the above holds true as a reason to get married, at least one of the parties is aware of the 'illegal' nature of this activity. This not only has severe penalties related to the immigration status of an individual, but also severe penal consequences under federal jurisdictions of most of the Global West, including Canada, and Germany (Asllani, 2016). Newspapers and press releases from the gatekeeping and fencing authorities; however, exaggerate the prevalence of this phenomenon by using headlines like 'Sham marriage network dismantled in Denmark and Germany' (Europol, 2018); or 'International students in fake marriage schemes in Canada' (Todd, 2017). Using terms like 'network' and 'marriage schemes', the media overstates the extent of the phenomenon, as the mass public then believe that the paper marriages that are happening has the ability to cause massive damage to the immigration and security of a country (Victor, 1998).

Some researchers (Satzewich, 2014; Wang, 2013; Jones, 1997) argue that individuals who get caught committing immigration fraud are often treated differently based on their race and ethnicity. For example, racialized men are more often deported, whereas white women citizens or permanent residents are often let go with a warning (Wang, 2013; Jones, 1997; Satzewich, 2014). This speaks to the targeting of the 'folk devils' from that of the minorities as described under moral panic (Cohen, 2011). The above adds to the bias that exists in the decision-making process of frontline officers. Perhaps the policies or training provided to these officers at their roots are biased and dated. As the world becomes more globalized and people are exposed to people of different cultures, mixed-race relationships are formed. Some cultures actively work to counteract this phenomenon by sticking to their traditions of arranged marriages like the South Asian communities. Many of these relationships do not conform to the western 
views of marriages, i.e., display and evidence of love and affection before marriage (Hier, 2019). People from South Asia often have their marriages arranged and that could mean that the bride and groom possibly are meeting each other for the first time during the eve of their wedding. All of this is not something that is coded in the border services' rule book to investigate paper marriages. Thus, resulting in a socially constructed definition of 'deviance', as explained under moral panic theory, of the people from a minority culture which doesn't resonate with the western definition of love and marriage (Victor, 1998). And thus, it is a critical realist and a subjective approach of inquiry and investigation by what they perceive as a potential paper marriage.

Attempted paper marriages are perceived as high risk to the integrity of the FRP in Canada. Proving fraud and the easy availability of fraudulent documents in some countries are thought of as two main reasons for why the extent and the true nature of 'paper marriages' are hard to determine (Evaluation Division, 2014). An online consultation conducted in 2010 by the CIC, revealed that over three-quarter of respondents recognized paper marriages as a threat to Canada's immigration system, and it was identified as a priority by the Minister of CIC in 2012 (Evaluation Division, 2014). Another survey of 38 Canadian Visa Offices Abroad (CVOA) that processes Family Class files, revealed that $78 \%$ of them found paper marriages in their caseloads and this was $16 \%$ of the total number of applications received (CIC News, 2017).

Paper marriages are happening; it is a reality as conceded by CBSA, IRCC (former CIC), and RCMP (House of Commons Canada, 2014), and also by Berlin branch of the Federal Office for Immigration and Refugees (BAMF) (The Local Germany, 2018). Lack of available resources and appropriate training to the immigration officers were recognized as something that challenges the FRP's integrity (Evaluation Division, 2014). Relaxed senior BAMF officers who 
repeatedly ignored dubious applications that were flagged by the frontline officers and refused to do a further investigation because of lack of resources, challenges FRs' integrity. Often genuine marriages from the East are flagged as paper marriages (Merali, 2015). In other instances, the existence of bias in human agents and passport reading machines in the borders have revealed a ‘suspect region’ bias (Dyer, 2019; Gaucher, 2014).

According to the Evaluation Division, (2014), and the United Kingdom's Home Office (2013), paper marriages are often entered by the below categories of people. Although, some of the below are types of potential people who may get into paper marriages is given by the UK's Home Office, (2013), the points all do apply to both Canada and Germany.

- A temporary resident who doesn't have the proper paperwork to stay in a country and have overstayed their visa already. This type is possible in case of people entering Germany or Canada as an international student, on a temporary resident visa, or on a tourist visa. Once in the country, these people would willingly overstay even after their visa expires.

- A temporary resident who has a visa, but it is unlikely that they can get an extension to their existing visa or residency status. This can happen to international students who are currently on their Post Graduate Work Permits (Canada), or they are on open workpermit or student visas which cannot be renewed again.

- A non-resident who has been refused an extension for their visa. Any temporary resident visa possessor with a refused extension could fall under this category.

- A non-resident who doesn't qualify to receive a visa on their own. These would be cases where foreigners either get into a contractual agreement to create a paper marriage or the 
foreigners trick citizens in the host country to form a part of the unilateral paper marriages. Unilateral marriages are more prone to happen in Canada than Germany as Germany doesn't have any sponsorship obligations to the spouse they sponsor, like providing living space, livelihood, health insurance, etc. Contractual marriages can happen in both countries.

- A couple of non-residents where one potential spouse has a higher probability of receiving a visa than the other spouse. This is one of the newest types of paper marriages where international student gateway programs of Canada and other English-speaking, immigrant-receiving countries are being circumvented by the border artists.

- $\quad$ Asylum seekers who strongly feel that their refugee claim would be denied because of increasing restrictions and regulations in the host country. In this case, contractual paper marriages are in rise as a movement of solidarity and marriage for residential security.

\subsection{Migrant marriage gateway in Canada:}

In 2001, the Immigration and Refugee Protection Act (IRPA) was launched in Canada that granted the government much more extensive powers to act as 'fencers', i.e., the authoritative bodies that were allowed to remove people living in the country at will, if these people were found to have used illegal means to enter Canada. Detaining and deportation of any immigrant landed or 'illegal' was made more straightforward for the government. The act also recognized same-sex and common-law relationships and allowed for family sponsorship of such couples (Dirks, 2006). According to this act, family reunification was recognized as a means to immigrate to Canada. At present, this has been the second mostly widely used category for immigration applications to Canada (Evaluation Division, 2014). The policies related to spousal sponsorship; however, have changed over the years, with changes in the government making 
family reunification tougher for some years and easier for others. In 2001, under Liberal Party majority of Prime Minister, Jean Chrétien, immigration under family class was strict. Under the Immigration and Refugee Protection Act (S.C. 2001, .c.27), a foreigner couldn't be sponsored as a spouse under A21(1) and R72(1)(e)(i) if they lacked status in Canada (Justice Laws, 2001). This was changed in 2005, when Liberal party minority government under Prime Minister Paul Martin, passed A25 where out of status spouses were also made eligible to be sponsored when an undertaking of three years was submitted under IP 2 and IP 8 by an R130 qualified sponsor, meaning the sponsor was over 18 and resided in Canada (CIC, 2005). Until 2005, marriage under IRPA was defined "the voluntary union for life of one man and one woman to the exclusion of all others." (Payne, 2001, p. 98). This definition was; however, altered with the passage of Civil Marriage Act in 2005, which defined marriage as "the lawful union of two persons to the exclusion of all others.” (Immigration Appeal Division, 2008, p. 5), to include same-sex marriages. Although minimum income requirements existed for sponsoring other members of the family, there was never a minimum income requirement for spousal sponsorship ever (Immigration Appeal Division, 2008). In 2008, conjugal partners were also deemed eligible to be sponsored to Canada; however, they were not considered "family members" under S. 1(3)(a) of the IRP Regulations. For marriage; however, requirements of formal validity in the jurisdiction where it took place, evidentiary issues of duly solemnized marriage and not just a registration and marriage certificate, as well as essential validity, i.e. "matters relating to consent to marry, existing prior marriage, prohibited degrees of relationship, non-consummation of the marriage, fraud, and duress" (Immigration Appeal Division, 2008, p. 7) was put in place. In 2012, the Conservative government, under Prime Minister Stephen Harper, declared that marriage of convenience was a top priority threat to the country's integrity and launched conditional 
permanent residency which was an adaption of spousal sponsorship policy from the UK (Gaucher, 2014). These measures later found to be ineffective and not truly reflective of the extent of the problem. The conditional permanent residency was later scrapped by the Liberal government in 2017 (Government of Canada, 2017).

Partner sponsorship today is broadly classified under spousal sponsorship, common-law partnership, and conjugal partnership [as defined under R130 and R1 (1)]. For this kind of sponsorship, Canada provides two ways of sponsoring, i.e., inland applications and outland applications. Spousal and common-law applications can be made both inland when the partner with a temporary visa and leave to stay in Canada can also work in Canada on an open work permit till a decision is made on their file, and also outland sponsorship where the partner being sponsored lives in another country (Government of Canada, 2019). A drawback of inland sponsorship; however, for the sponsoree is that they cannot leave the country for the 12 or so months required to finalize the claim if they don't have a valid visa and permit to return. If they do leave Canada, their inland application is forfeited and they must start an outland application all over again (Government of Canada, 2019a). Another drawback of inland application is that if an application is rejected there is no scope for appeal. The rejected sponsoree must leave Canada when their temporary visa expires (Sponsorship Lawyer Toronto, 2019). In the case of outland sponsorship, which is also the only way of sponsoring a conjugal partner, the partner can still apply for a visitor visa to enter Canada and stay with their partner. In this case; however, they are not eligible to work. The sponsor takes an undertaking of three years, to be responsible for the financial and basic needs of the sponsoree including food, clothing, shelter and other needs of day to day living as well as eye care, dental and other health care needs that are not covered by public health services. This undertaking is a promise to Canada which is not resolved even if the 
marriage breaks up, the sponsoree moves to another province or country, if they become Canadian citizen or even if the sponsor faces financial hardship (Government of Canada, 2019).

To prevent chain sponsorship of spouses (a way to counteract paper marriage phenomenon), a person cannot sponsor a spouse if they themselves were sponsored as a spouse to Canada and it hasn't been five years since then. And also, a person cannot sponsor a spouse if they had sponsored a spouse previously and it hasn't been three years since (Government of Canada, 2019). Under the Trudeau government, the conditional permanent residency of two years that required a sponsoree to live with their sponsor for two years minimum if they didn't had a child together or face removal, that was in place under the Harper government on marriage migrants had been erased in 2017, and overall the noose of immigration has been loosened (Government of Canada, 2017). The press release by CIC stated that "by removing the condition, the Government recognizes that, while cases of marriage fraud exist, the majority of relationships are genuine and most spousal sponsorship applications are made in good faith" (Government of Canada, 2017, para. 3). This news release also terminated all investigations on the relationships that were alleged to be paper marriages during the time of Harper government (Government of Canada, 2017).

All inland marriages in Canada require a marriage license, that can be obtained in Registry Services and in some cases online. To procure the license, a valid passport, birth certificate, driving license, and citizenship card is required from both parties (Settlement.org, 2018). If one of the spouses was widowed, a death certificate of the former spouse and marriage certificate from the previous marriage is required with an affidavit. In case of divorce in Canada of a spouse, an original copy of divorce decree or court-certificate of divorce is required. In case of divorce in another country, an endorsement from the Ministry of Government Services is 
required before a marriage license is granted by the Registrar. Once, the marriage license is obtained, the couple have 90 days to either do a civil or a religious wedding. In case of religious wedding, banns of marriage are often required to be published. Two witnesses over 18 years of age and minister or the marriage officiant who presided over the wedding, then fills the marriage registration form that are then sent to Division of Vital Statistics. A Solemnization of Marriage which acts as a temporary proof of marriage is then issued by the minister or the marriage commissioner and next an application must be made to the Division of Vital Statistics to get the marriage certificate (Kalyani, 2018; Settlement.org, 2018). This marriage certificate then becomes one of the many documents that are required to apply for spousal sponsorship in Canada.

Thus, in case of inland marriages, the Registrar at the Registry Services, the Ministry of Government Services, the Minister or the Marriage Officiant are all tasked with determining whether a marriage is genuine or for papers only. These gatekeepers along with the CIC (IRCC) who may or may not accept the sponsorship application and CBSA officers who may or may not permit to land as permanent resident are all other barriers that Canada has in place to catch paper marriages. In case of outland marriages, this responsibility of gatekeeping falls to the CVOAs and the CBSA officers. Cases under investigation of suspicion of paper marriages fall under the purview of RCMP officers and this part is then described as fencing as given by Triandafyllidou \& Ambrosini (2011).

\subsection{Migrant Marriage gateway in Germany:}

In the European Union, right to family reunification is laid down in the Family Reunification Directive (FRD) (2003/86/EC) and Union Citizens Directive (UCD) (2004/28/EC). 
Since, Germany is a member state, its residency rights are also governed by the same directives. Germany; however, along with other member states often faces tension between upholding this right and securitization of its borders (de Hart, 2017). Both FRD and UCD do have provisions and recognizes paper marriages. On July 02, 2009 the European Commission's communication provided with '2009 Commission Guidelines' to tackle paper marriages. These guidelines provided member states with legal framework to assist in detecting and investigating cases of paper marriages. However, the burden of proof still lied on the member states and cases were often thrown off citing lack of substantial proofs and severe encroachment on private and intimate life. (de Hart, 2017; EUR-Lex, 2014).

After multiple requests from the member states, the EC published "a handbook on marriages of convenience, including indicative criteria to assist in the identification of sham marriages" (EUR-Lex, 2014, para. 2), in 2014. This brought about an interesting shift of the burden of proof from the member states to the couples (de Hart, 2017). In this policy document, it was declared that "Despite the limited number of cases, the implication of organised criminal networks, as acknowledged in recent Europol reports, is worrying." (EUR-Lex, 2014, para. 4). The handbook confirmed the many Europol reports and validated the links of paper marriages to illegal syndicates and crimes like forced marriages, trafficking, smuggling, and forgery. In the EU Policy cycle 2014-2017, a strategic goal \# 4 was included to fight paper marriages and the phenomenon was declared as an 'organized and serious international crime'. Various national authorities along with Commission agencies, like Europol, had formed joint forces to enable further operational exchange between Member States to tackle the issue of paper marriages. In the Handbook, the EC also declared that 'sole purpose' in its definition of paper marriages as "marriage contracted for the sole purpose of conferring a right of free movement and residence 
under EU law on free movement of EU citizens to a spouse who would otherwise not have such a right" (EUR-Lex, 2014, para. 12), meant 'predominant purpose' and not 'unique or exclusive purpose'. Thus, putting into investigation many more marriages.

Germany, and other Member States of EU's FR differs from Canada in such that the spouses or same-sex life partners are not sponsored. That is, the spouse who is an EU citizen, simply has to apply to the country for their foreign spouse's residency permit under $\S 23$ Section 1 AuslG (Ausländergesetz = foreigner law) $($ German Law Archive, 1999). "Within the Marriage Act the spouse without German citizenship has gained the right to claim residential allowance under $\S 23$ Sec.1 Nr. 1 AusIG (Ausländergesetz = foreigner law), provided that the spouse holding the German citizenship resides in Germany" (Voss, 2013, p. 3). The EU citizen does not take an undertaking to meet basic or financial needs of the foreign spouse. The only requirements for this are that both spouses must attend an in person interview, be over 18 years of age, have basic German language skill and have primary residence in Germany. Documents required for this process includes the application form, valid passport or Personalausweis (personal identification card), marriage certificate, language certificate, Meldebestätigung (certificate of registration of main address in Germany), and all foreign documents translated to German with the authenticity certificate from the German consular office. All marriages are required to last a minimum of three years. Two years together and one year separate for a renewal or extension of the foreign spouse's residency permit (Landesamt für Bürger-und Ordnungsangelegenheiten, 2019). For the renewal, an integration certificate by attending Registration Office for Foreigners's integration course is also mandatory (Landesamt für Bürger-und Ordnungsangelegenheiten, 2019; Bundesministerium der Justiz und fur Verbraucherschutz, 2017). It has become a practice recently that the residency permit is only granted for one year, 
and after that the couple is required to confirm their Zusammenleben (commitment to married life) to the foreigner's office. If this office perceives a case of paper marriage in this case, they can issue a date for Scheinehen-Anhörung ("fake-marriage" hearing) (Voss, 2013). Thus, acting as fencers to remove the offenders from the country (Triandafyllidou \& Ambrosini, 2011).

Inland marriages in Germany, can be a complicated affair, and almost never possible for people who do not have an existing right to stay or Grenzübertrittsschein (proof of entrance). A foreigner or refugee out of the threat of deportation can apply for an asylum as a right to stay, but the application will almost always be rejected if a previous asylum application was made and denied, and thus marriage for residential security is one of the best options available in today's politics (Schmidt \& Griese, 2003). To get married, the couple must first go to a Standesamt (Registrar's office), who is by law required to deny their cooperation ( $§ 1310$ BGB), if they perceive the marriage to be a fictitious marriage ( $\$ 1314$ Sect. 2) to get the list of documents required for the wedding depending on the country of origin of the foreign spouse (Bundesministerium der Justiz und fur Verbraucherschutz, n.d.). Thus, acting as the first gatekeeper. In case of same-sex partnership, this job role is assigned to the Notar (notary). Birth certificate, Ehefähigkeitszeugnis (Affidavit of single status), passport, and other specific documents from the country of origin is required for this purpose. These documents must then be presented to the German Embassy for authenticity testing under the Consular Act, $\S 13$

Konsulargesetz. Countries of West Africa and Vietnam where fraudulent documents are easy to procure, sometimes take a long time as Heimatstandesamt (Registrar of the partner's country of origin) insists on validating the original documents. For foreigners, whose home country don't have the provision of Ehefähigkeitszeugnis, a testimony from the Oberlandesgericht (high court) is required. In this case, the Standesamt is then required to send the remaining documents to the 
Oberlandesgericht as well, which becomes a tedious task without a lawyer. Once all the documents are received by the Standesamt, a date of marriage is determined following a period of Aufgebotsverfahren (mandatory public notice of the intention to marry).

In case of Germany, thus the registrar's office, foreigners office, social office and notary along with Europol are all tasked to be the gatekeepers and fencers and thus uphold to the country's bordering from within (Wray, 2011; Yuval-Davis, Wemyss, \& Cassidy, 2018; YuvalDavis, Wemyss, \& Cassidy, 2017).

The German Residence Act of 2004 is restrictive to only spouses/ partners or minor children and not extended family. The extended family can be granted residency only if it is necessary to prevent hardship under Section 36 AufenthG (Kreienbrink \& Ruhl, 2007). Germany also does not require the sponsors to prove that they are financially capable to provide for their sponsored spouse or child. Because of this leniency, Germany has been targeted and receiving a particular type of paper marriages called Fake-Father Paper Marriages. Under this, a pregnant woman pays a German man to declare that he is the father of the child. The child receives German citizenship, and the mother receives the right to live in Germany (BBC, 2017). Another type of paper marriage that is surfacing in Germany is also in form of protective marriage or marriage for solidarity. The lack of financial burden on the resident spouse, perhaps could be a reason of why compassion, care, and social obligations become reasons for some Germans who stand for open borders and people's right to choose where they want to live. This is also called marriage for residential security (Schmidt \& Griese, 2003). 


\subsection{Migrant Marriages as Synonymous to Paper Marriages:}

Paper marriages are often presented as a threat to genuine international marriages, especially from cultures where arranged marriages are common and expected, and in cases where marriage is seen as the only way to live together for cross-national couples who then choose the country that provides the opportunity for the best economic and social benefits for the couple and their future family (Wray, 2015). The gatekeepers find it hard to fathom an arranged marriage where pre-wedding contacts and prior affections are neither required nor typical (Triandafyllidou \& Ambrosini, 2011). Love is expected to develop over time (Merali, 2015). There are also some cultural quirks that possibly throw off an investigating officer with no to little knowledge of foreign cultures. For example, marriage between first cousins is quite common within the Muslim communities of South Asia; however, it isn't the case for the Hindus (Merali, 2015). Germany's FR would not grant residency to anyone who might be closely related in blood as a spouse, and hence, Muslims from South Asia may face a harder time (Kreienbrink \& Ruhl, 2007). Canada's FRP has a similar rule; however, close relations are defined as grandparentgrandchild, parent-child, and brother-sister relations by blood or adoption only (Government of Canada, 2019).

D’Aoust (2017), argues that Western romantic love or the proof of love or 'pure relationship' is tied to state concerns about race, citizenship, and inclusion. Marriage migration management has now entered the realm of state security policies that rely heavily on the moralpolitical economy of suspicion, this then builds on governmental regulations that tie to the classification of different rights for different groups (D'Aoust, 2017). This further ties to Crossman (2019)'s explanation of moral panic which says that "Moral panics are often centered around people who are marginalized in society due to their race or ethnicity, class, sexuality, 
nationality, or religion. As such, a moral panic often draws on known stereotypes and reinforces them. It can also exacerbate the real and perceived differences and divisions between groups of people. Moral panic is well known in the sociology of deviance and crime and is related to the labeling theory of deviance" (para. 2). This creates a 'us' vs them' attitude in society, where 'us' are the law-abiding locals of the immigrant-receiving countries like Canada and Germany and 'them' are the folk devils or the foreigner others trying to take advantage of the liberal welfare states and its residents (Somers, 2015).

The newspaper's role as such as the moral entrepreneurs of society causes perhaps more damage to the minority relations in society. Wang (2013), found that a review of the people selected for questioning of the legitimacy of their marriages by border services seems to be people in mixed marriages. It also reveals that people who 'lawyer up' to go to the immigration interviews are also often subjected to an assumption of fraud. As Wang (2013) puts it "a client who is an immigrant woman will always be in a position marked by the law's assumption of fraud, and her attorney always read as a possible subject who coaches.” (p. 1237). This then points to the possible existence of gendered and racialized discrimination in the selection process for fraud examination (Wang, 2013). A leaked "Evidence of Relationship" guide for Canada's visa officers and CBSA (as cited in Keung, 2015), gives some warning signs to look out for. Among them are:

- "University-educated Chinese nationals marrying non-Chinese

- Photos without parents or any family members, just a small group of friends

- Private marriage ceremony performed by either a minister or justice of the peace

- Informal reception in a restaurant

- Sponsor is uneducated, with a low-paying job or on welfare

- The couple do not kiss on the lips in photos

- Couples who do not have a honeymoon, not even a couple of days away, usually because of university and/or no money

- There are no "diamond" rings 
- Wedding photos done professionally but pictures are very limited

- Some submit photos dressed in pajamas or cooking, to show they are living together

- Photos have them wearing the same clothes in various locations

- Are they touching each other in the photos, or trying not to touch?

- Photos of activities taken in the Niagara Falls area, Niagara-on-the-Lake and Toronto" (para. 21).

As lawyer Go puts it "If this is the kind of training that immigration officers are getting, one really has to wonder about the quality and competence of the officers who are making decisions that will make or break a family. It also calls into question the credibility of the entire decision-making process.” (as cited in Keung, 2015, para. 16).

\subsection{Conclusion:}

While getting into a paper marriage for money, for deceit, for compassion or for friendship, is still a criminal offence in both Canada and Germany punishable by fines, imprisonment, and deportation. Despite these some people still take the risk. It is crucial to recognize and address any covert or even unintentional biases that may exist amongst the people tasked with the responsibility to grant or refuse family reunification to an individual. Looking at the media in both countries we can gain insights as to the role of newspapers in shaping public opinion and causes behind anti-immigrant biases.

\section{Chapter 5. Findings and Analysis:}

This chapter provides a discourse analysis of media representations of paper marriages in German and Canadian newspapers between 2000-present. Using characteristics of moral panics as underlined by Goode \& Ben-Yehuda (1994)'s attributional model, 'volatility', 'hostility', 'measurable concern', 'consensus', and 'disproportionality'. This review will utilize newspapers and press releases from The Globe and Mail, Toronto Sun, and CBC in Canada, and The Local 
Germany and Spiegel from Germany. An initial review of the articles shows that they construct and define the phenomenon of paper marriages as a social problem that needs immediate attention. A detailed analysis of the period 2000-2019 shows that even though, these newspapers tend to represent different ideological stance, they generally present paper marriages as a form of fraud, and a criminal act. Furthermore, on testing the few articles in Germany that are presented to the tune of protection marriages, it is evident, that the moral panic is morphing into a 'good' moral panic as given by Hier (2016). That is, the newspapers in Germany are now presenting opinions that support the activists' and border artists' position on paper marriages as well. Thus, providing the German public with a 360-degree view on paper marriages and allowing them to choose for themselves, what narrative they would support.

\subsection{Paper Marriages as moral panic:}

Goode \& Ben-Yehuda (1994) gave five indicators of moral panic which they argued to be social constructs and the collective behavior of the masses in reaction to the scares and persecutions (Victor, 1998; Abend, 2008; Buchanan, Shaw, Ford, \& Singer, 2003; Pijpers, 2006; Maneri, 2018). They are 'volatility', 'hostility', ‘measurable concern', ‘consensus', and 'disproportionality', as described in later sections (Goode \& Ben-Yehuda, 1994). "The content of claims about deviance include matters such as: stereotypes of deviants and their behavior, typologies of variations among deviants, descriptions of the dangers and particular harms caused by deviants and rationales for dealing with deviants" (Victor, 1998, p. 544). All of these was observed in the narratives of the phenomenon of paper marriages by the five selected newspapers and press releases between 2000-present. As such, the phenomenon of paper marriages was concluded to be a moral panic. 


\subsubsection{Volatility:}

Volatility is defined as eruption and subsiding of a concern suddenly in a society against a section of people considered as moral deviants (Goode \& Ben-Yehuda, 1994). This is often done to show that the politicians are doing something to take care of the real corruption in the society. Measurable success or success stories in return tend to show that the problem was indeed present, and the panic created was indeed warranted (Pijpers, 2006). Before the Conservative government in Canada launched conditional permanent residency in Canada in 2012, newspapers were full of articles that provided information to the masses about the grievousness of the situation around paper marriages. In an article in The Globe and Mail, it was said:

"Immigration Minister Jason Kenney confirmed the plan Wednesday, singling out China and India as countries where elaborate schemes have been uncovered. Mr. Kenney said Canadian officials in India noticed that the faces of husbands and wives were being Photoshopped onto the same wedding photo, time and again." (Curry, 2011, para. 6).

Another press release by CBSA as quoted in Toronto Sun, called out Chinese Canadians as fraudsters who were operating syndicates to get Chinese immigrants to marry Canadians by paying between $\$ 30,000-\$ 35000$ (Robertson, 2013). Another article in $C B C$ reported:

"In February 2007, officials with Citizenship and Immigration Canada (CIC) requested an investigation into "the high number of potential fraud cases related to possible marriages of convenience" in the Punjab region in India, according to internal documents obtained under the Access to Information Act." (McKie, 2010, para. 2).

We see here, a targeting of specific communities (Indian and Chinese in Canada), who were presented as deviants, challenging the integrity of Canadian immigration system. An interesting observation here would be categorically singling out or 'othering' of certain minority groups. This is observed in all three Canadian newspaper that were selected. Thus, we see that 
the ideological inclination of the newspaper doesn't change the fact that paper marriages were construed to be a deviant act.

Furthermore, Maneri (2018) states that "an important point to take into account is the fact that often moral panics appear in series" (p. 46). First, a politician would point to a societal issue that needs immediate attention. Second, the news media would pick up the politician's statement and do a story about it. Third, other news sources then pick up the same story quoting the said politician and try to get responses from other politicians regarding the said issue. Similar and opposing viewpoints of the politicians are presented in the news. Finally, to complete the circle of moral panic, media would then garner opinions or statements from locals who fit the narratives presented by the politician and present it to the public to showcase how terrible the situation is (Maneri, 2018). In Germany, Spiegel, published an article that speaks to the panic and the fear amongst the local people of the newcomers. Speaking about asylum seekers from Nigeria, Morocco and Gambia, a local in Baden-Württemberg complains:

"At 4 p.m. a week ago Monday, men could be seen passing by on the street every few minutes. "It's hell at night," Fessler says. "They buy booze at the discount supermarket, get drunk or stoned at the train station and in the park and then stagger by us on their way back." He says he's unable to sleep half the night and that he feels like he's being terrorized." (Der Spiegel, 2018, para. 57).

The act of getting drunk and high, and walking in the streets creating a ruckus, although could be construed as a nuisance, but pointing out that the area is home to many asylum seekers from West Africa demonstrates the biases towards this group. By using headlines like "Migrant smuggling and sham marriages: Organised crime group dismantled" (Europol, 2018); and issuing statements to that tune, the press releases by the 'gatekeeping and fencing' authorities perpetrates 
that the problem is quite significant; and necessary measures need to be taken to curb the phenomenon. For example:

"Currently, the CBSA has a number of criminal investigations under way into suspected marriage of convenience fraud and will continue to pursue cases as they come to the Agency's attention. As well, the Agency has removed sponsored partners from Canada for having misrepresented themselves (as per section 40(1) of the Immigration and Refugee Protection Act). In 2011, 104 people were removed from Canada for misrepresentation, which includes marriage fraud. Our efforts at detecting and stopping this type of fraud, along with those of CIC and the RCMP, demonstrate the Government's commitment to ensure the integrity of our immigration system." (Radia, 2012, para. 19).

The actions taken by the relevant authorities then reflects the rationales for taking care of the moral deviancy. 'Removal of 104 people from Canada for misrepresentation', then becomes a justified measure for corrupting the Canadian society by exploiting the Canadian immigration system (Victor, 1998). Interestingly, when the Liberal government in Canada removed the conditional permanent residency in 2017, all the cases under investigation on suspicion of paper marriages were dropped as well (Government of Canada, 2017).

\subsubsection{Hostility:}

The moral deviants as defined by Goode \& Ben-Yehuda (1994), face intense hostility from the society. They are thought of as enemies of the state and wish to corrupt the society. In Germany, this can be seen in the 2010 book by the populist politician Thilo Sarrazin called 'Deutschland schafft sich ab' translated as 'Germany does itself in' (Piwoni, 2018); where Sarrazin targeted the Muslim immigrants as wanting to destroy the German culture and identity by their 'fondness for procreation', once again defining a stereotypical behavior of these 'deviants' or 'folk devils' as wanting to have many children. An underlying message here is the 'Muslims of West Africa' by procreating and having more children than the native German 
population are trying to destroy the whiteness of Germany. This book sold over 1.5 million copies by 2012 and has been in the Spiegel Best-Seller list for 21 weeks (Warrior, 2012). Thus, speaking to this rising populist sentiments in Germany, a Spiegel article exclaims:

"Germany has obviously become a country of immigration - and one that is changing rapidly. And although economists and politicians are fond of emphasizing all the positive aspects of this development - Germany's aging society, for example, has been an issue for decades - there's also a large segment of society that is anything but pleased by the development." (Der Spiegel, 2018, para. 8).

Another article in The Globe and Mail about a rejected spousal sponsorship application by CIC presents statements that show the hostility against an immigrant spouse is also present in the family members of the person who marries a foreigner. The family thinks that the person got into a marriage of convenience by deceit. This represents the interests of the nation and the family and friends of an individual who knows that a person has married not for love like they believe, but naively to be a line jumper's ticket to Canada.

"The poisonous words on Immigration Department letterhead arrive just as the bride is parrying barbs from certain family members and colleagues who have begun to voice their concern over this marriage. Yet, the judgmental correspondence signed by the anonymous bureaucrat is the unkindest cut of all. It is the official seal of disapproval. The woman has erred; she has been unwise and naive, prompting her government to prevent further foolishness, embarrassment and injury to her and to her country" (Rekai, 2008, para. 3).

Immigration and family sponsorship are a very contested issue, with the public and politicians taking platforms at the extreme ends of the spectrum. Maxime Bernier of People's Party Canada, a Prime Minister candidate for Canada's 2019 federal election, was quoted as saying that he would completely eradicate the family sponsorship and create border walls. This message of his in Mississauga, a very diverse neighborhood in Ontario, Canada, was apparently received with much applause from the public (Shivji, 2019). Bernier presented his reasoning for 
wanting to eradicate family sponsorship by saying that Canada cannot be the welfare state of the planet (Dib, 2019). Thus, stereotyping immigrants as people who are looking to take advantage of the Canadian society and thus justifying his action to cancel all family sponsorship as a means to an end (Victor, 1998).

\subsubsection{Measurable Concern:}

Measurable concern speaks to the ability of the threat been measured in concrete terms using attitude surveys, faulty empirical data, and data representation in terms which accentuates the threat by a lot. An instance of this in Germany can be seen in a Spiegel article, which reported that according to a case study, the judges calculated that the number of fictitious marriages rose by 20 percent in the past year alone (Ludwig, 2005). This article fails to give information on what the numbers actually were for the past year. The article also reported that the Federal Ministry of the Interior determined that around 3,000 marriages per year were pursued for investigation as fictitious marriages throughout Germany. Once again, a failure to report how many of those were conclusively proven as paper marriages was not provided. The article; however, mentions that the 3,000 were just the registered cases (Ludwig, 2005), that is the ones that the officials were investigating, thus presupposing value judgement that many paper marriages were not caught and hence the need for the securitization of the immigration system.

Another article in The Globe and Mail, points to the fact that many immigration consultants in Canada are suggesting foreigners to get into paper marriages to gain residency. It also suggests that many of these consultants are not even registered and thus freely advise foreigners to break rules (Jimenez, 2005). One other article claimed, 
"Citizenship and Immigration says there are no firm figures on the extent of marriage fraud, but in 2010, about 16 per cent of the 46,300 immigration applications for spouses and partners were refused for various reasons, including that the relationship was not bona fide. When Canada increased its focus on fraud originating from southern China via Canada's mission in Hong Kong, the rejection rate there for spouses increased to 50 per cent in 2008" (Curry, 2011, para. 17).

In the above excerpt, we see multiple aspects of moral panic taking place. First, a stereotype creation of people from Hong Kong with a 50 percent increase in rejections due to fraud. Second, we see presentation of numbers. And third, we see 'the rejection of sponsorship application' as the justified measure to curtail the phenomenon of paper marriages. What this article further doesn't speak of, are the appeal rates for these rejected applications. Interestingly, in a 2002 report, Leslie Macleod determined that approximately 40\% of spousal sponsorship rejection cases resulted in an appeal and overturning of the decisions. The article further fails to give information on the hardship cost to the families in terms of lost time whose sponsorship application was denied and later approved. This article also fails to speak of the gross success rate of correct judgements issued the first time around, and also fails to speak of the cost to Canadian tax payers in terms of cost for these appeals (House of Commons, Canada, 2009).

A Toronto Sun article presented accounts of the case of Wei Ren, a Chinese-Canadian who was put under house-arrest for two years for operating a 'marriage of convenience factory'. What was interesting in this case was that apparently this 'factory' of Ren's went on for over seven years; however, the judge still didn't find the case was strong enough to warrant imprisonment (Mandel, 2015). 
"By the time the Canadian Border Services Agency grew suspicious and mounted Project Honeymoon, the permanent residency applications of 130 Chinese students were linked to Ren's marriage of convenience factory" (Mandel, 2015, para. 4).

In this case, we see another target group for moral panic, the international students trying to stay in Canada through marriage fraud, thus creating a typology (Victor, 1998). Another way the newspapers exaggerates moral panic is through extrapolation. This is done by providing a parallel fact, which could be used as the extend of corruption. This is primarily using information as a tool to presuppose value judgements (Abend, 2008). An article, quoting former Canadian citizenship court judge, Shinder Purewal in Vancouver Sun states: "Families are looking for matches to get their sons or daughters abroad. And the most successful route to Canada is through international-student channels. It's an easy way to get immigration" (Todd, 2017, para. 18). The same article also points out that "B.C. is home to 130,000 international students, the vast majority of whom are in Metro Vancouver, which has the highest concentration of foreign students in Canada" (Todd, 2017, para. 14). This reporting exaggerates the potential problem of paper marriages among international students by giving the impression that all 130,000 international students in B.C. could potentially try to stay in Canada through paper marriages.

Another alarmist article in The Globe and Mail presented measurable concern with absolutely no backing for the data source or the number.

"Ms. Green is just one of 1,500 Canadians who fall victim to marriage fraud each year, according to an advocacy group called Canadians Against Immigration Fraud. Falling in love with foreigners, they are jilted weeks - if not days - after the vows are exchanged." (Bielski, 2009, para. 7).

The group, Canadians Against Immigration Fraud, are advocating for people whose spouses defrauded the system. They want their partners removed from Canada and stripped of their permanent residency. This speaks to what Victor (1998) says about the rise of the moral 
crusades. "A moral panic often gives rise to social movements aimed at eliminating the threatening deviants and may generate moral crusades and political struggles over use of the law to suppress the dangerous deviants" (Victor, 1998, p. 543)

The Local Germany reported another type of paper marriage which they termed as 'fake fatherhood'. With the article's headline saying "German men selling fatherhood to refugee women for cash, say prosecutors" speaks to the extend of this type of paper marriages. Measurable concerns are then provided as:

"[U]p to 700 fake fatherhood recognitions have been sold to women over the last few months in Berlin." And "In one case reported on by rbb, 70 pregnant Vietnamese women lived in one Berlin house linked to the deceit. But the transactions are reportedly taking place across the country, with many women also coming from Africa and eastern Europe." (The Local German, 2017, para. 5).

\subsubsection{Consensus:}

Consensus speaks to the general, almost blanket agreement amongst the population which perceives a risk to be real and the potential damage severe. Examples of this can be seen in The Globe and Mail articles some with headlines that say "Many Canadians who sponsor a foreign spouse find themselves jilted" (Bielski, 2009), and others which presented a blanket statement that paper marriages were apparently 'common' in South Asian community. It read:

"Marriages of convenience are common in the South Asian community, and because of this, spousal sponsorships are scrutinized closely to ensure people are not marrying for immigration purposes" (Jimenez, 2006, para. 11).

Once again, fueling the stereotype of South Asians as the 'folk devils' in the phenomenon of paper marriages. Other times, the issues are presented in a way that forces a consensus on public. For instance, the CVOA's action and expectations are presented to show, that the chances 
of finding bonafide marriages in binational marriages are minimal. Canadian 'middle-aged' women are presented as naïve and potential victims of paper marriages.

"Canadian immigration offices located in sunny vacation locales are busy at this time of year. It is when (young) local men file applications to immigrate to Canada; applications sponsored by their brand new (older) Canadian wives. The immigration officers have seen all this before - it's practically a rite of spring. Middle-aged women on "winter break" hooking up with young men from resorts; an unseemly parade of waiters, beachcombers and hotel entertainment directors, all booking a one-way ticket out of the Third World via the matrimonial express" (Rekai, 2008, para. 1).

This is another type of typology that is created 'older naïve women as victims and young foreigner men as evil doers'. This typology is repeated in another article in Spiegel, "Immigraten Oma und Kellner" translating to 'Immigration Grandmother and waiter'. This article is about the marriage between a 25-years-old waiter from Tunisia and an 83-year-old German woman. The Tunisian was denied residency visa because of doubts about his serious marriage intent. This typology is present in Canada as well. One application of South Asian couple was denied with reasons given as:

"You and your sponsor are incompatible in terms of age. Whereas an age difference of 5 - 7 years in favour of the male is considered an acceptable norm in your community, your sponsor (female) is 9 years older than you" (House of Commons, Canada, 2009, 0915, para. 2).

Once again speaking to stereotyping and type casting deviants in this moral panic of paper marriages. This is a consensus that older men marrying younger women from offshore is a legitimate relationship and transcends all borders and cultures; however, older women marrying younger offshore men are deemed to need state protection to curb their naivety about their marriage. 
"In Canada, the mature male is being "high-fived" by drinking buddies impressed with his new, young foreign bride. Meanwhile the disappointed Canadian female informs friends and family that her new marital life has been nixed by the government" (Rekai, 2008, para. 8).

\subsubsection{Disproportionality:}

Disproportionality can be explained by lack of empirically verified harm that can be associated with the harm done by the moral deviants. "Even though the measurable concern is great, the numbers of deviants are minimal or even non-existent and their harm is very limited or even non-existent." (Victor, 1998, p. 543). One can argue that to nix the issue of immigration fraud in its bud, the only viable option is to have open borders. However, scholars like Snel (2003), argue that open borders would lead "to uncontrollable consequences, to overstretch threatening our society's character" (Snel, 2003, p. 15).

$C B C$ reported that in the three years between 2008-2010, a conviction rate of $0.015 \%$ was obtained by the CBSA in the 200 possible leads on paper marriages. Total number of family sponsorships granted in 2008 was 65,580, in 2009 it was 65,206, and in 2010 it was 60,207 (Statistics Canada, 2015). To put the disproportionality more into perspective, the 3 convictions were obtained up on a review of 190, 993 applications.

"Between 2008, when the agency began compiling figures, and [2010], it had received some 200 leads on possible marriage fraud from various sources. Of these, 39 warranted a formal investigation, with charges laid in seven cases, including three convictions. As of December 2010, 17 of the cases remained open" (The Canadian Press, 2011, para. 11).

News like this fail to tell the public, the cost to taxpayers such investigations cause. It also fails to inform the public the story of the person who perpetuated the said fraud. Could it be that the person was merely looking for an opportunity to better their life and had no other option 
but to commit this fraud because of the very restrictive immigration policies that were present in the country they grew to love? Another article in The Local Germany stated that:

"Police arrested five suspects, including four women, as they carried out raids in more than 40 locations across the German capital, Berlin police and prosecutors said in a statement.” (The Local Germany, 2017, para. 1).

The above reflects a success rate of $12.5 \%$. However, the cost to the taxpayers for these raids conducted is not shown. An interesting pattern that is noted in these articles is that it almost always presents details of money exchanging hands. For example: "while in Nigeria the gang charged men up to $€ 13,000$ for the scheme" (The Local Germany, 2017, para. 1); or "Wei Ren, aka Christine Ren and Christine Molson, wept as she was sentenced to two years less a day of house arrest for orchestrating an elaborate scheme where 130 Chinese students paid her $\$ 35,000$ each for marriage to a Canadian sponsor" (Mandel, 2015, para. 2). This should be a good reason to reflect that the immigrants, almost always get the short end of the stick. If caught, they get deported; however, the citizens or the members of organized crime groups like Wei Ren get away with a slap in the wrist in the form of house arrest. This also speaks to the disproportionality of the punishments given to the migrants to that of the citizens.

\subsection{Paper Marriages as (Good?) Moral Panic:}

Moral panics are generally seen as regressive and conservative reactions, reinforcing social inequalities (Jenkins, 2009). Using the concept of 'good' moral panic, Cohen (1999, 2003, 2011), pointed out that panics could often operate with progressive bent by the activists who would then behave as moral entrepreneurs trying to correct the social injustices. Cohen (2001)'s work on states of denial, explicitly focussed on the ethical importance of promoting 'good' moral panics. For Cohen (2001), “a human rights imperative oriented towards exposing, disrupting, and 
reversing the cognitive, emotional, and cultural mechanisms of denial that thwart unfettered recognition of violence, atrocity, suffering, and injustice" (as cited in Hier (2016), p. 868), is what is needed. These 'good' moral panics can be harnessed to relieve the persistent human sufferings and human cruelty to one other (Hier, 2016).

Butler (2009) theorized about the ambivalent nature of the regulatory and the constitutive effects of moral panics that moves beyond the conventionally collated view that they are regressive and conservative. Butler (2005), says that human ties and dependency on one another leads to 'social obligations', which then supports the inception of ethical responsibilities that one life feels for the other. Hier (2016) gives examples of a situation of a moral panic against police violence against Black youths \#BringBackOurGirls campaign in Nigeria and the expansion of \#BlackLivesMatter. He says all these are examples of the 'good' moral panic that happened and came mainly from the left based ideologies. "It is at the intersection of corporal vulnerability as a universal feature of existence and the specific ways that injuries and injustices are inflicted on precarious populations [that] locates the possibility of and imperatives for progressive social obligations", (Hier, 2016, p.881).

In case of paper marriages as 'good' moral panic, the discourse is still in its infancy in Germany, and almost non-present in Canada. Spiegel published an article, in its opinion column, on changing discourse of paper marriages towards it being a 'protective marriage' called "History of a fictitious marriage The Trau Schein". It read: 
"There are many reasons to marry: love, Torschlusspanik, taxes - but also solidarity. With refugees and migrants threatened with deportation. Scheinehe means that in the official German, Schutzhehe call it the activists. The story of a man who decided to marry to help." (Wiedemann, 2012, para. 1).

This speaks to an alternative act of solidarity and 'compassion' whereof the man who decided to help a woman gain residency status in Germany by getting into a protective marriage with her.

Another article in Spiegel although proposed that a young 25-year-old man, cannot fall in love with an 83-year-old grandmother; it also included the concept of marriage for compassion. It read:

"Das Abenteuer wagen aber auch Deutsche, die im Auslandsurlaub Einheimische kennen lernen und diese aus Mitleid über die ärmlichen Verhältnisse ins reiche Europa holen möchten. Und es gibt Multikulti-Organisationen, die mit der Vermittlung von Zweckehen das restriktive deutsche Asylrecht umgehen möchten” (Ludwig, 2005, para. 6).

This translates to the Germans seeking adventure also go to foreign lands and marry someone out of 'compassion and care' to remove the person from poor conditions. It also spoke about the multicultural organizations that helps with protective marriages to circumvent the German asylum system. This speaks to the 'social obligation' that some people or even organizations find themselves in to support other humans who wishes to only better their lives

An activist organization called Schutzehe in Germany, gives information to people and opines that "Marriage is a possibility to protect people from deportation" (Schmidt \& Griese, 2003, para. 1). In this regard, the moral panic of paper marriages can be thought of as anti-denial movement as well and can be argued as 'acceptable'. Thus, developing a binary in the discourse of the phenomenon of paper marriage as a moral panic (Panchev, 2013). 


\subsection{Findings and Analysis - Conclusion:}

From this chapter we can conclude that both Canada and Germany have very stringent measures in place to curtail the spread of paper marriages. The newspapers and news releases in general, in both countries, criminalizes the phenomenon of paper marriages and have extrapolated the whole issue of paper marriages to a level that now is considered to be a situation of moral panic. In Germany; however, another discourse of protective marriages that almost normalizes the phenomenon of paper marriages is emerging. Although, still in its infancy in Germany, this discourse has the potential to bring about a complete discussion on rights of people to choose better living conditions and opportunities for themselves and their families. This discourse currently presents all the characteristics of 'good' moral panic as given by Hier (2016), that is 'compassion', 'care' and 'social obligation'. Acknowledging, that good and bad are subjective value judgments, this chapter concludes that paper marriages as moral panic have reached a 360-degree discourse in Germany, where people are given options to choose how they view paper marriages. Whether it is people breaking laws or whether it is people choosing to better their lives and that of their families. The same development cannot; however, be concluded for Canada.

\section{Chapter 6. Conclusion:}

The discourse on paper marriages in Canada and Germany reflect increasing desire for regulating immigration in a political climate that is increasingly hostile towards immigration. This study used the theoretical frameworks of border controls, to understand the concepts of gatekeepers and fencers in Canada and Germany, and concluded that both these countries have very stringent methods in place to catch paper marriages. 
Using critical discourse analysis on five newspapers, news releases along with policy documents and parliamentary minutes of meetings from Germany and Canada, I examined how paper marriages have been represented in the media and how these representations reached a level of moral panic in both countries. After a review of the theories of marriage migration and family reunification, it was clear that both the countries have adopted stringent policies and empowered many gatekeepers and fencers to keep the population of the country the way they want. The theory of moral panic was used as an analytical framework to study the media portrayals of paper marriages. Using Goode and Ben-Yehuda's attributional model of moral panic, I examined instances of 'volatility', 'hostility', 'measurable concern', 'consensus' and 'disproportionality', as it appeared in the newspapers and news releases in both Canada and Germany. My research further revealed that while paper marriages are seen as a form of fraud by some, there are also others who justify it as a form of solidarity to assist those who try to better their lives.

The discourse of paper marriages also reflects the existing hostilities towards 'others', especially people from the global South. In an environment of rising xenophobia, applicants who are applying for family reunification would be treated with suspicion and distrust. The underlying biases in the gatekeepers often also make the authorities take incorrect decisions about the suspect cases of paper marriages.

While my sample size and limited analysis does not allow me to make broad generalizations about these two countries, I observe that even though Canadian government presents a very liberal front and is showing a pro-immigrant attitude in general, the media analysis tells a different story. Canadian media regardless of its political inclination, has in the last two decades portrayed the migrant marriages in particular and immigrants in general in a 
negative light, who are looking to take advantage of Canada's generosity as a welfare state. Germany on the other hand, have become more stringent in its rules as have the other member states of the EU. While initially, EU put the onus of proof on the countries to prove that a migrant marriage was not genuine, since 2014, this onus has shifted towards the couple. Canada's spousal sponsorship has a requirement that the sponsoring spouse is financially responsible for the sponsored spouse for three years; however, in Germany, such a requirement is not present. This could be seen as a potential reason as to why the discourse on paper marriages as 'protective marriages' is gaining grounds in Germany but is not present in Canada.

With its small sample size and limited data sources, this paper provides us some preliminary observations paper marriages as moral panic in both Canada and Germany. This study also does not provide stories and points of view of people who experienced the accusation of paper marriage. For future research, interviews of couples in migrant marriages, whether bonafide or fake would be very helpful to understand their interactions with the various gatekeepers and fencers of the countries. Due to time shortages in getting ethics clearance conducting individual interviews, I decided not to include any interviews in this study. Having ethics clearance to conduct field study on protection marriages in Canada and Germany would have added a lot of value to this study. A content analysis of the number and episodes of reporting on paper marriages and occurrences of the keywords related to paper marriages in the media would also be useful to gain insights to see if there are certain historical patterns associated with political events in both countries. Expanding the sample size to a greater number of newspaper and political inclinations would also be helpful. 


\section{References:}

Abend, G. (2008). Two Main Problems in the Sociology of Morality. Theory and Society, 37(2), $87-125$.

Abrams, K. (2012). Marriage Fraud. California Law Review, 1-67.

Aldous, J. (1990). Family Development and the Life Course: Two Perspectives on Family Change. Journal of Marriage and Family, 571-583.

Alkousaa, R. (2017). German police arrest five in raid of Nigerian 'husband' smuggling ring. Berlin: Reuters.

Anderson-Dixon, C. (2013). Has the medias creation of moral panics caused our society to decline? Western Eye.

Appadurai, A. (1991). Global Ethnoscapes: Notes and Queries for a Transnational Anthropology. In R. Fox (Ed.), Recapturing anthropology: working in the present (pp. 191-210). School of American Research Press.

Arango, J. (2000). Explaining migration: Explaining migration. International Social Science Journal, 52(165), 283-296.

Arat-Koc, S. (1999). Neoliberalism, State Restructuring and Immigration: Changes in Canadian Policies in the 1990s. Journal of Canadian Studies, 34(2), 31-56.

Archer, M., Rutzou, T., Decoteau, C., Smith, C., Gorski, P., Steinmetz, G., . . Porpora, D. (2016). What is Critical Realism. Perspectives . 
Asllani, G. (2016). Dissecting Marriage Fraud as a True Immigration Crime. MDPI Laws, 1-10.

Aulakh, R. (2010, Jul 16). Fastest way to get to Canada-Marriage. Toronto Star.

Bacon, D. (2008). Illegal People: How Globalization Creates Migration and Criminalizes Immigrants. Beacon Press.

Bale, T., \& Hampshire, J. (2012). Immigration policy. In Cameron and the Conservatives. London: Palgrave Macmillan.

Baran, J. (2000). Introduction to mass communication: Media Literacy and Culture. Boston: McGraw Hill.

BBC. (2017). Germany sees rise in fake father scams with immigrants. BBC.

Beck, U. (2004). The cosmopolitan vision, Der kosmopolitische Blick. Cambridge: Polity Press.

Beck-Gernsheim, E. (2011). The Marriage Route to Migration: of border artistes, transnational matchmaking and imported spouses. Nordic Journal of Migration Research, 1(2), 60-68.

Benson, M., \& Charsley, K. (2015). From genuine to sham marriage: moral panic and the 'authenticity' of relationships. In M. Benson (Ed.), Revisiting Moral Panic (pp. 221-230). Bristol: Policy Press.

Bielecki, J. (2019, Jan 29). Germany relocates so much to other EU countries as never before. Retrieved from Süddeutsche Zeitung: https://www.sueddeutsche.de/politik/fluechtlingedeutschland-schiebt-so-viel-in-andere-eu-staaten-ab-wie-nie-zuvor-1.4295346 
Bielski, Z. (2009, Apr 30). Many Canadians who sponsor a foreign spouse find themselves jilted. Retrieved from The Globe and Mail: https://www.theglobeandmail.com/life/relationships/many-canadians-who-sponsor-aforeign-spouse-find-themselves-jilted/article570171/

Bijak, J. (2006). Forecasting international migration: Selected theories, models, and methods.

Bledsoe, C. (2004). Reproduction at the margins: migration and legitimacy in the New Europe. Demographic Research, 3(4), 87-114.

Böcker, A. (1994). Chain migration over legally closed borders: settled migrants as bridgeheads and gatekeepers. The Netherlands' Journal of Social Sciences, 30, 87-104.

Bonjour, S., \& De Hart, B. (2013). A proper wife, a proper marriage: Constructions of "us" and 'them' in Dutch family migration policy. European Journal of Women's Studies, 20(1), $61-76$.

Brislin, R. (1976). Comparative research methodology: Cross-cultural studies . International Journal of Psychologj, 215-229.

Brislin, R., Lonner, W., \& Thorndike, R. (1973). Cross-cultural research methods. New York: John Wiley.

Brown, L. (2015). Wanted: Green Card: Marrying for Citizenship. Brown One Publishing.

Buchanan, D., Shaw, S., Ford, A., \& Singer, M. (2003). Empirical Science Meets Moral Panic: An Analysis of the Politics of Needle Exchange. Journal of Public Health Policy, 24(3/4), 427-444. 
Bundesministerium der Justiz und fur Verbraucherschutz. (2017). Act on the Residence, Economic Activity and Integration of Foreigners in the Federal Territory Residency Act. Bundesamt fur Justiz.

Bundesministerium der Justiz und fur Verbraucherschutz. (n.d.). Civil Code (BGB). Bundesamt fur Justiz.

Burroughs, E. (2015). Discursive representations of 'illegal immigration'in the Irish newsprint media: The domination and multiple facets of the 'control'argumentation. Discourse \& Society, 26(2), 165-183.

Butler, J. (2005). Giving an Account of Oneself. New York: Fordham University Press.

Butler, J. (2009). Frames of War. New York: Verso.

Cadman, D. (2015). One-Sided Marriage Fraud: Who Looks Out for the Citizen Victims? Center for Immigration Studies.

Canada.gc. (2019). Cracking Down on Immigration Fraud. Canada.gc.ca.

Caplan, B. (2019). How Open Borders Died in Five Countries. The Library of Economics and Liberty.

Carling, J. (2011). The European paradox of unwanted migration. A threat against Europe, 3346.

Çelikaksoy, A., Skyt Nielsen, H., \& Verner, M. (2004). Marriage Migration: Just another case of positive assortative matching? . In Working Paper 03-27. Department of Economics, Aarhus School of Business . 
Charsley, K., \& Benson, M. (2012). Marriages of Convenience, and Inconvenient Marriages: regulating spousal migration to Britain. Journal of Immigration, Asylum and Nationality Law, 10-26.

Chase, J. (2017, Sep 29). German election: What do the terms 'right' and 'left' mean, if both $C D U$ and SPD are in the center? Retrieved from DW.com: https://www.dw.com/en/german-election-what-do-the-terms-right-and-left-mean-if-bothcdu-and-spd-are-in-the-center/a-37601594-0

Chen, J. (1994). The Harris- Todaro model of labor migration and its commercial policy implications. Iowa State University.

CIC. (2005). IP 8 Spouse or Common-law partner in Canada Class . Citizenship and Immigration Canada.

CIC News. (2017). Latest Data Reveals Insight into Marriages of Convenience. CIC News.

Cohen, S. (1999). Moral panics and folk concepts. Paedagogica Historica, 35(3), 585-591.

Cohen, S. (2001). States of Denial. London: Polity.

Cohen, S. (2003). Folk Devils and Moral Panics: The Creation of the Mods and Rockers. London: Routledge.

Cohen, S. (2011). Folk Devils and Moral Panics. London: Routledge.

Cropanzano, R., \& Mitchell, M. (2005). Social Exchange Theory: An Interdisciplinary Review. Journal of Management, 874-900. 
Crossman, A. (2019). A Sociological Understanding of Moral Panic.

Cuen, L. (2016). "Marriage Fraud" Is a Thing — And It's More Common Than You Think. Mic.

Curr, M. (2018). Do you take thee? The costs of a visa marriage of convenience. The Citizen.

Curry, B. (2009, Jan 22). Marriage was genuine, Guinean immigrant tells panel. Retrieved from The Globe and Mail: https://www.theglobeandmail.com/news/national/marriage-wasgenuine-guinean-immigrant-tells-panel/article1147482/

Curry, B. (2011, Oct 26). Ottawa moves to curb marriages of convenience. Retrieved from The Globe and Mail: https://www.theglobeandmail.com/news/politics/ottawa-moves-to-curbmarriages-of-convenience/article4182749/

D'Aoust, A. (2013). In the Name of Love: Marriage Migration, Governmentality, and Technologies of Love. International Political Sociology, 7(3), 258-274.

D'Aoust, A. (2017). A moral economy of suspicion: Love and marriage migration management practices in the United Kingdom. Environment and Planning D: Society and Space, $36(1), 40-59$.

David, P. (1998). Path dependence, its critics and the quest for 'historical economics'. European Association for Evolutionary Political Economy. Athens.

De Armas, M. (2007). For richer or poorer or any other reason: Adjudicating immigration marriage fraud. Journal of Gender, Social Policy \& the Law, 15(4), 743-767.

de Hart, B. (2017). The Europeanization of Love. The Marriage of Convenience in European Migration Law. European Journal of Migration and Law, 281-306. 
Der Spiegel. (2018, Apr 19). The Changing Face of the Country. Retrieved from Spiegel: https://www.spiegel.de/international/germany/germany-and-immigration-the-changingface-of-the-country-a-1203143.html

Dib, L. (2019, Jul 25). Maxime Bernier promises to cut immigration, build border fences in platform speech. Retrieved from The Globe and Mail: https://www.theglobeandmail.com/politics/article-maxime-bernier-promises-to-cutimmigration-build-border-fences-in/

Dirks, G. (2006). Immigration Policy in Canada. The Canadian Encyclopedia.

Dominick, R. (2002). The dynamics of mass communication: Media in the digital age. New York: McGraw Hill.

Dullabh, V. (2013). Is your marriage "legitimate?": A Critical discourse analysis of Canada's policy on marriage fraud. Toronto.

Dustmann, C., \& Glitz, A. (2005). Immigration, jobs and wages: Theory, evidence and opinion.

Dyer, E. (2019). Bias at the border? CBSA study finds travellers from some countries face more delays. CBC News.

Eggebø, H. (2013). A real marriage? Applying for marriage migration to Norway. Journal of ethnic and migration studies, 39(5), 773-789.

Ellis, B. (1990). Introduction: Contemporary Legends in Emergence. Western Folklore, 49(1), 17. 
EUR-Lex. (2014). Handbook on addressing the issue of alleged marriages of convenience between EU citizens and non-EU nationals in the context of EU law on free movement of EU citizens. Commission Staff Working Document 5201SC0284.

Europol. (2017, Sep 13). Nigerian Sham marriage criminal network dismantled in Germany and Portugal. Europol.

Europol. (2018, Aug 24). Migrant smuggling and sham marriages: Organised crime group dismantled. Retrieved from Europol: https://www.europol.europa.eu/newsroom/news/migrant-smuggling-and-sham-marriagesorganised-crime-group-dismantled

Europol. (2018). Sham Marriage network dismantled in Denmark and Germany. Europol.

Evaluation Division. (2014). Evaluation of the Family Reunification Program. Government of Canada.

Faist, T., \& Faist, T. (2000). The volume and dynamics of international migration and transnational social spaces. Oxford: Oxford University Press.

Fassin, E., \& Salcedo, M. (2015). Becoming gay? Immigration policies and the truth of sexual identity. Archives of sexual behavior, 44(5), 1117-1125.

Feerick, J. (2006). How an Earthquake Spawned Massive Immigration Fraud. Mental Floss Magazine.

Fleischer, A. (2007). Family, obligations, and migration: the role of kinship in Cameroon. Demographic Research, 14(13), 413-440. 
Fleischmann, F., \& Dronkers, J. (2010). Unemployment among immigrants in European labour markets: an analysis of origin and destination effects. Work, Employment \& Society, 24(2), 337-354.

Fussell, E., \& Massey, D. (2004). The limits to cumulative causation: International migration from Mexican urban areas. Demography, 41(1), 151-171.

Gaucher, M. (2014). Attack of the marriage fraudsters!: An examination of the Harper government's antimarriage fraud campaign. International Journal of Canadian Studies, $50,187-206$.

German Law Archive. (1999). Aliens Act (Ausländergesetz, AuslG) - Excerpt. Gerhard Dannemann.

Goode, E., \& Ben-Yehuda, L. (1994). Moral Panics: The Social Construction of Deviance. Cambridge: Blackwell.

Government of Canada. (2012). The Jig is Up on Marriage Fraud' says Minister Kenny. New.gc.ca.

Government of Canada. (2017). Notice - Government of Canada Eliminates Conditional Permanent Residence.

Government of Canada. (2019). Guide 5525 - Basic guide: Sponsor your spouse, partner or child.

Government of Canada. (2019a). Can I leave Canada while IRCC processes my application for permanent residence? 
Guba, E. (1990). The Paradigm Dialog. Newbury Park, London, New Delhi: Sage Publications.

Hagen-Zanker, J. (2008). Why do people migrate? A Review of the Theoretical Literature. Munich.

Hammar, T., Brochmann, G., Tamas, K., \& Faist, T. (1997). International Migration Immobility and Development: Multidisciplinary Perspectives. London: Bloomsbury Academic.

Happer, C., \& Philo, G. (2013). The Role of the Media in the Construction of Public Belief and Social Change. Journal of Social and Political Psychology, 321-336.

Haque-Hausrath, S. (2008). No human being is illegal. Helena, Montana: The Border Crossing Law Firm.

Herman, E., \& Chomsky, N. (2010). Manufacturing Consent: The Political Economy of the Mass Media.

HEUNI. (2016). Exploitative Sham Marriages: Exploring the links between Human Trafficking and Sham Marriages. European Institute for Crime Prevention and Control.

Hier, S. (2016). Good moral panics? Normative ambivalence, social reaction, and coexisting responsibilities in everyday life. Current Sociology, 65(6), 867-885.

Hier, S. (2019). Moral panic and the new neoliberal compromise. Current Sociology.

Home Office. (2013). Sham Marriages and Civil Partnerships: Background information and proposed referral and investigation scheme. Home Office. 
House of Commons Canada. (2014). Standing Committee on Citizenship and Immigration. CIMM Committee Meeting.

House of Commons, Canada. (2009, Nov 03). CIMM Committee Meeting. Retrieved from OurCommons: https://www.ourcommons.ca/DocumentViewer/en/40-2/CIMM/meeting32/evidence

Huzdik, K. (2014). Migration potential and affecting factors in Hungary in the first decade of the 21st century. Gödöllő: Szent István University Doctoral School of Management and Business Administration.

Immigration Appeal Division. (2008). Sponsorship Appeal and Protection Act. Immigration and Refugee Protection Board.

Infantino, F. (2014). Bordering «fake» marriages? The everyday practices of control at the consulates of Belgium, France and Italy in Casablanca. Etnografia e ricerca qualitativa, $7(1), 27-48$.

Institute XYZ. (1999). No human being is illegal - a handbook for a campaign. Berlin: ID Publishing House.

Jenkins, P. (2009). Failure to launch. British Journal of Criminology, 49(1), 35-47.

Jennissen, R. (2004). Macro-economic determinants of international migration in Europe. Amsterdam: Rozenberg Publishers. 
Jimenez, M. (2005, Feb 16). RCMP make arrest in immigration case. Retrieved from The Globe and Mail: https://www.theglobeandmail.com/news/national/rcmp-make-arrest-inimmigration-case/article975594/

Jimenez, M. (2006, Jun 01). Red tape swept aside, couple to reunite at last. Retrieved from The Globe and Mail: https://www.theglobeandmail.com/news/national/red-tape-swept-asidecouple-to-reunite-at-last/article4109222/

Jimenez, M. (2018, Apr 23). Arranged marriages becoming more common, officials say. The Globe and Mail.

John, T. (2010). A Study of Fraudulent Migratory Marriages in Canada and India . Toronto: Faculty of Law, University of Toronto.

Jones, J. (1997). The Immigration Marriage Fraud Amendments: Sham Marriages or Sham Legislation? Florida State University Law Review, 679-701.

Justice Laws. (2001). Immigration and Refugee Protection Act (S.C. 2001, c. 27). laws.justice.gc.ca.

Kalyani, M. (2018). Getting Married on a Tourist Visa in Canada. Marriage and Immigration.

Kelly, J., \& Casciani, D. (2010). How to get a sham marriage if you are illegal in the UK. BBC News.

Keung, N. (2008, May 23). Rent-a-guest schemes tipped off immigration. Toronto Star.

Keung, N. (2013). Marriage fraud: Canadian immigration officials tread thin line. The Star. 
Keung, N. (2015, May 19). Immigration guide for detecting marriage fraud called 'racist and offensive'. Toronto Star.

KhosraviNik, M. (2010). The representation of refugees, asylum seekers and immigrants in British newspapers. Journal of Language and Politics, 9(1), 1-28.

Kim, M. (2010). Gender and international marriage migration. Sociology compass, 4(9), 718731.

Kreienbrink, A., \& Ruhl, S. (2007). Family Reunification in Germany. Federal Office for Migration and Refugees.

Kritz, M., Lim, L., \& Zlotnik, H. (1992). International migration systems: a global approach. Oxford: Oxford Clarendon Press.

Kurekeva, L. (2011). Theories of migration: Conceptual review and empirical testing in the context of the EU East-West flows. Interdisciplinary conference on Migration. Economic Change, Social Challenge. . University College London .

Kurekova, L. (2011). Theories of migration: Conceptual review and empirical testing in the context of the EU East-West flows. Interdisciplinary Conference on Migration, Economic Change, Social Challenge.

Kwok, S. (2019). My Father Was a Paper Son. Angel Island Immigration Station Foundation.

Landesamt für Bürger-und Ordnungsangelegenheiten. (2019). Residence permit for spouses, parents and children of German citizens. Berlin: Berlin.de.

Lash, S., \& Urry, J. (2007). Globale Kulturindustrie. Frankfurt: Suhrkamp. 
Lau, E. (2007). Paper Families: Identity, Immigration Administration, and Chinese Exclusion. Durham: Duke University Press.

Ludwig, U. (2005, Oct 31). Immigraten Oma und Kellner. Retrieved from Spiegel: https://www.spiegel.de/spiegel/print/d-42903250.html

Malcolm, C. (2018, Aug 22). MALCOLM: Trudeau's approach to immigration is losing public support. Retrieved from Toronto Sun: https://torontosun.com/opinion/columnists/malcolm-trudeaus-approach-to-immigrationis-losing-public-support

Mandel, M. (2015, May 28). Matchmaker of bogus marriages gets house arrest. Retrieved from Toronto Sun: https://torontosun.com/2015/05/28/matchmaker-of-bogus-marriages-getshouse-arrest/wcm/abaeff69-cc96-49cb-9580-208a6fb5c8b6

Maneri, M. (2018). Media hypes, moral panics, and the ambiguous nature of facts. Urban security as discursive formation. In P. Vasterman (Ed.), Media Hype to Twitter Storm. News Explosions and Their Impact on Issues, Crises, and Public Opinion (pp. 39-60). Amsterdam: Amsterdam University Press.

Massey, D. (1990). The Social and Economic Origins of Immigration. The Annals of the American Academy of Political and Social Science, 60-72.

Massey, D., Arango, J., Hugo, G., Kouaouci, A., Pellegrino, A., \& Taylor, J. (1993). Theories of international migration: a review and appraisal. Population and development review, 19(3), 431-466. 
McKie, D. (2010, Nov 08). Marriages of convenience problems persist. Retrieved from CBC: https://www.cbc.ca/news/politics/marriages-of-convenience-problems-persist-1.876101

McLaughlin, E. (2014). See also Young, 1971: Marshall McLuhan, moral panics and moral indignation. Theoretical Criminology, 18(4), 422-431.

McLuhan, M. (1967). Understanding Media: The Extensions of Man. London: Sphere.

Media Bias Fact Check LLC. (2019). Media Bias/ Fact Check: Toronto Sun. Media Bias Fact Check LLC.

Merali, N. (2015). An Insider Viewpoint on Cultural Norms for Marriage and Mate Selection Relevant to. University of Alberta.

Meurrens, S. (2017). There were problems with Conservatives' law to combat marriage fraud; its repeal was positive. The current system is not perfect, but generally works. Vancouver: Policy Options.

Myall, R. (2019). Discovering A Paper Son. Ellis Island: The Statue of Liberty - Ellis Island Foundation.

Nancy, N. (2018). Should we Keep this Quiet? Print Media and Child Marriage in Nigeria. Global Media Journal, 16-31.

North, D. (2016). Good News and Bad About an Immigration/Marriage Fraud Case. Center for Immigration Studies.

O'Brien, J., \& Kollock, P. (1991). Social Exchange Theory as a Conceptual Framework for Teaching the Sociological Perspective. Teaching Sociology, 140-153. 
Palriwala, R., \& Uberoi, P. (2008). Exploring the links: gender issues in marriage and migration. In R. Palriwala, \& P. Uberoi (Eds.), Marriage, migration and gender (pp. 23-62). London: Sage .

Panchev, D. (2013). Good Moral Panics and Late Modern Condition. London: LASALA Foundation.

Payne, M. (2001). Ch. 2; Modernization of Benefits Act, S.C. 2000, c. 12, s. 1.1 . In Canadian Family Law.

Pellander, S. (2015). An acceptable marriage" marriage migration and moral gatekeeping in Finland. Journal of Family Issues, 36(11), 1472-1489.

Petruk, T. (2014, Jul 31). BC lawyer sues Vietnamese bride for ditching him one week after he helped her move to Canada. National Post.

Piché, V. (2013). Contemporary Migration Theories as Reflected in their Founding Texts. Population, 141-164.

Pijpers, R. (2006). 'Help! The Poles Are Coming': Narrating a Contemporary Moral Panic. Geografiska Annaler. Series B, Human Geography, 88(1), 91-103.

Piwoni, E. (2018). Mass-mediated discourse on emotion, and the feeling rules it conveys: The case of the Sarrazin debate. Current Sociology.

Prakash, N. (2009). The development impact of workers' remittances in Fiji. Massey University.

Qu, S. (2016). Canada's spousal sponsorship process: Challenges of cross-national couples. Toronto: Ryerson University. 
Quan, D. (2016). How a B.C. man pulled off one of the most sophisticated immigration frauds in Canadian history. Vancouver: National Post.

Ravenstein, E. (1889). The Laws of Migration. Journal of the Royal Statistical Society, 241-305.

Regan, P., Jerry, D., Narvaez, M., \& Johnson, D. (1999). Public displays of affection among Asian and Latino heterosexual couples. Psychological Reports, 1201-1202.

Rekai, P. (2008, May 20). Whose marriage? Whose convenience? Retrieved from The Globe and Mail: https://www.theglobeandmail.com/opinion/whose-marriage-whoseconvenience/article719821/

Robertson, I. (2013, Jan 18). Seven GTA women accused of arranging bogus marriages. Retrieved from Toronto Sun: https://torontosun.com/2013/01/18/seven-gta-womenaccused-of-arranging-bogus-marriages/wcm/2a6e38c9-0052-4dc4-92b8-e09c647a9152

Satzewich, V. (2014). Canadian visa officers and the social construction of "real" spousal relationships. Canadian Review of Sociology.

Saunders, D. (2019, Jun 29). Justin Trudeau vs. the world: How the next government can reclaim Canada's place on the international stage. Retrieved from The Globe and Mail: https://www.theglobeandmail.com/opinion/article-justin-trudeau-vs-the-world-how-thenext-government-can-reclaim/

Schmidt, E., \& Griese, H. (2003). Protection marriage-Marrying for the purpose of residential security. Bremen: Silke Wagner.

Settlement.org. (2018). Can I Get Married in Canada on a Visitor Visa? OCASI. 
Shields, J., Drolet, J., \& Valenzuela, K. (2016). Immigrant Settlement and Integration Services and the Role of. Ryerson Centre for Immigration and Settlement.

Shivji, S. (2019, Jul 24). Maxime Bernier says his party would cap immigration levels at $150 \mathrm{~K}$. Retrieved from CBC: https://www.cbc.ca/news/politics/maxime-bernier-immigrationspeech-mississauga-1.5224114

Simmons, A. (1987). Explaining migration: Theory at the crossroads. In J. Duchne (Ed.), Explanation in the Social Sciences: The Search for Causes in Demography (pp. 73-92). Louvain-la-Neuve, Belgium: Universite catholique de Louvain, Institut de demographie.

Somers, S. (2015). Marriage Fraud and Asian Migrant Communitites. UBC.

Sponsorship Lawyer Toronto. (2019). What Happens If You Marry a Canadian Citizen. Sponsorship Lawyer Toronto.

Stark, O. (1991). The migration of labor. Cambridge: Basil Blackwell.

Stark, O., \& Bloom, D. (1985). The New Economics of Labor Migration. The American Economic Review, 173-178.

Stark, O., \& Bloom, D. E. (1985). The new economics of labor migration. The American Economic Review, 75(2), 173-178. Retrieved 3 10, 2019, from https://popline.org/node/407292

Statistics Canada. (2015). Tables for Migration: International 2009. Statistics Canada.

Strasser, E., Kraler, A., Bonjour, S., \& Bilger, V. (2009). Doing family: Responses to the construction of the "migrant family" across Europe. History of the Family, 165-176. 
The Canadian Press. (2011, Nov 01). Marriage fraud targeted by Canada border agency.

Retrieved from CBC: https://www.cbc.ca/news/politics/marriage-fraud-targeted-bycanada-border-agency-1.1003652

The Library of Congress. (2015). Citizenship Pathways and Border Protection: Germany. The Library of Congress.

The Local German. (2017, Jun 06). German men selling fatherhood to refugee women for cash, say prosecutors. Retrieved from The Local German: https://www.thelocal.de/20170606/german-men-selling-fatherhood-to-refugee-womenfor-cash-say-prosecutors

The Local Germany. (2017, Sep 12). German police bust Portuguese-Nigerian sham marriage ring. The Local de.

The Local Germany. (2018). Berlin immigration authorities enabled years' long fraud: report. The Local Germany.

The United Nations. (1948). Universal Declaration of Human Rights- Article 16.

Timmer, A., \& Williams, J. (1998). Immigration Policy Prior to the 1930s: Labor Markets, Policy Interactions, and Globalization Backlash. Population and Development Review, 739-771.

Timmerman, C. (2008). Marriage in a 'Culture of Migration'. Emirdag Marrying into Flanders. European Review, 16(4), 585-594. 
Todaro, M. (1969). A Model of Labor Migration and Urban Unemployment in Less Developed Countries. The American Economic Review, 138-148.

Todd, D. (2017). International students in fake marriage schemes to Canada. Vancouver Sun.

Triandafyllidou, A., \& Ambrosini, M. (2011). Irregular immigration control in Italy and Greece: Strong fencing and weak gate-keeping serving the labour market. European Journal of Migration and Law, 251-273.

UNHCR. (2017). UNHCR Statistics: The World in numbers. UN.

van Dijk, T. (1995). Aims of Critical Discourse Analysis. Japanese Discourse, 17-27.

Vertovec, S. (2002). Transnational Networks and Skilled Labour Migration. Ladenburger Diskurs "Migration" Gottlieb Daimler- und Karl Benz Stiftung. Ladenburg.

Victor, J. (1998). Moral Panics and the Social Construction of Deviant Behavior: A Theory and Application to the Case of Ritual Child Abuse. Sociological Perspectives, 41(3), 541565.

Voss, J. (2013). Niemand ist eine Insel. Bremen: Gesellschaft für Aktuelle Kunst.

Walt, V. (2008). Field of dreams. Time, 42-49.

Wang, L. (2013). "Of the Law, but Not Its Spirit": Immigration Marriage Fraud as Legal Fiction and Violence Against Asian Immigrant Women . UC Irvine Law Review, 1221-1250.

Wang, W. (2012). The Rise of Intermarriage. Pew Research Center. 
Warrior, R. (2012, May 21). How Sarrazin Became a Millionaire. Retrieved from Handelsblatt: https://www.handelsblatt.com/unternehmen/it-medien/lukratives-buch-wie-sarrazinmillionaer-wurde/6647994.html?ticket=ST-12688682-pJIgyhXIxduFzEeHiKWk-ap3

Weaver, G. R., \& Trevino, L. K. (1994). Normative And Empirical Business Ethics: Separation, Marriage Of Convenience, Or Marriage Of Necessity? Business Ethics Quarterly, 4(02), 129-143. Retrieved 3 10, 2019, from http://journals.cambridge.org/abstract_s1052150x0001126x

Welch, M. (2006). Scapegoats of September 11th. New Brunswick, NJ: Rutgers University Press.

Wickramasinghe, A., \& Wimalaratana, W. (2016). International migration and migration theories. Social Affairs: A Journal for the Social Sciences, 1(5), 13-32.

Wiedemann, C. (2012). History of a fictitious marriage The Trau-Schein. Spiegel Online.

Williams, L. (2010). Global Marriage: Cross-Border Marriage Migration in Global Context. London: Palgrave Macmillan.

Wray, H. (2011). An ideal husband? Marriages of convenience, moral gate-keeping and immigration to the United Kingdom. In The First Decade of EU Migration and Asylum Law (pp. 351-373). Brill Nijhoff.

Wray, H. (2015). The 'pure' relationship, sham marriages and immigration control. In J. Miles, R. Probert, \& P. Mody (Eds.), Marriage Rites and Rights. Hart Publishing. 
Young, J. (1971). The Drugtakers: The Social Meaning of Drug Use. London: McGibbon and Kee.

Yuval-Davis, N., Wemyss, G., \& Cassidy, K. (2017). Everyday Bordering, Belonging and the Reorientation of British Immigration Legislation. Sociology, 52(2), 228-244.

Yuval-Davis, N., Wemyss, G., \& Cassidy, K. (2018). 'Beauty and the beast': Everyday bordering and 'sham marriage'discourse. Political Geography, 66, 151-160.

Yuval-Davis, N., Wemyss, G., \& Cassidy, K. (2018). 'Beauty and the beast': Everyday bordering and 'sham marriage'discourse. Political Geography, 66, 151-160. 